\title{
Estrategias Psicoconductuales e información para Odontólogos y pacientes que requieran procedimientos de Odontología Pediátrica durante la etapa de la pandemia COVID-19
}

Asociación Latinoamericana de Odontopediatría. Equipo Interdisciplinario COVID-19

\section{Introducción}

Ante la situación de pandemia por Coronavirus, se han desarrollado los siguientes documentos desde la Asociación Latinoamericana de Odontopediatría (ALOP), para apoyar a los Odontopediatras, a la comunidad y a las familias sobre cómo abordar la atención odontológica de los niños durante el período de esta crisis sanitaria.

La pandemia COVID-19 ha llevado al cierre de las prácticas odontológicas en todo el mundo. Sin embargo, según el estado de pandemia, algunos países están reabriendo actualmente o planean reabrir sus servicios odontológicos como parte de una salida a la estrategia de cierre. Debido a la necesidad urgente de tener una guía para la toma de decisiones, se realiza esta revisión basada en la mejor evidencia disponible. En esta situación de pandemia en evolución, la información proporcionada por cada país puede estar sujeta a cambios. ${ }^{1}$

El objetivo es brindar orientación básica a padres, tutores y grupo familiar de aquellos niños que requieran tratamiento odontológico durante el periodo de pandemia por Coronavirus. Estas medidas incluyen orientación sobre los cambios en la modalidad de atención de las consultas de odontopediatría, manejo en casa para una mejor convivencia, medidas a tomar en cuenta para acudir a la consulta dental, antes de salir de casa, durante el trayecto de ida y vuelta a la consulta dental y cuidados al volver al hogar. Estas recomendaciones están basadas en la información científica disponible hasta la fecha, incluyendo publicaciones y lineamientos de organismos de salud internacionales, así como los publicados por la Asociación Latinoamericana de Odontopediatría ALOP. Esta información puede estar sujeta a cambios futuros, por lo que se insta realizar seguimiento a las actualizaciones de este material.

Los documentos están redactados en un lenguaje que permita ser comprensible en todos los países asociados y en el caso de los niños, en modalidad más lúdica anexando cuentos escritos y en video para evidenciar las nuevas formas de atención odontológica por motivo del COVID-19. 
En el caso de los padres se han desarrollado documentos para apoyar el manejo de esta crisis desde el punto de vista del ambiente familiar y además para colaborar en el entendimiento de las medidas para controlar el contagio del virus, una lista de cotejo de actividades para antes, durante y después de la consulta odontológica, en modalidad texto y video.

\section{Características de la consulta Odontológica durante la Pandemia COVID-19}

En la actualidad la pandemia COVID-19 se encuentra en diferentes grados de expresión y los países que conforman ALOP se encontrarán en distintas etapas de atención odontológica, lo que requiere una amplia gama de medidas que aplicar de acuerdo con las circunstancias de cada uno.

Durante la atención de pacientes niños en las diferentes fases de la pandemia, las opciones de tratamiento y su planificación pueden variar. Los países han implementado diferentes medidas para la prestación general de atención odontológica, incluso durante las fases de "infección humana generalizada" de la pandemia que conducen a los picos de infección. ${ }^{2}$

Durante la etapa de confinamiento o cuarentena, se debe realizar la atención odontológica únicamente a pacientes que presenten urgencias y emergencias, y suspender el tratamiento dental no esencial, electivo. De ser posible, realizar atención mediante teleodontología ya sea por teléfono o mediante el uso aplicaciones. Se debe realizar un interrogatorio de los signos y síntomas del niño, que permitan obtener un diagnóstico presuntivo con un manejo sintomático. El uso de fotos y videos, así como de video llamadas, puede ayudar a mejorar el diagnóstico. De no ser posible manejar y controlar la urgencia mediante teleodontología, el paciente deberá acudir a la consulta para ser atendido. Solo se atenderán pacientes que presenten: pulpitis irreversible severa, pericoronaritis, absceso dentoalveolar, alveolitis, hemorragia, trauma dentoalveolar con fractura dental, avulsión o luxación. ${ }^{3-5}$

Durante todo el período de pandemia COVID-19 se deben utilizar alternativas de tratamiento que no generen aerosoles y tomar todas las precauciones correspondientes con el uso del equipo de protección personal (EPP). ${ }^{3-4}$

A medida que los países van superando las etapas más críticas, la atención odontológica se extiende a tratamientos electivos, como primeras consultas, tratamientos sucesivos o controles pendientes. En estas etapas los protocolos cambian, pero se mantienen normas especiales de control de infección tanto en la consulta como en la vestimenta del personal de salud y del paciente. ${ }^{1-3}$

\section{Relación Odontólogo - Paciente - Representante}

La Odontopediatría es una especialidad que exige mucho del profesional desde el punto de vista psicológico. El especialista en niños debe tener empatía afectiva, que es la habilidad para entender los pensamientos y sentimientos del paciente $\mathrm{y}$ actuar de una forma adecuada a ellos. El Odontopediatra debe realizar comentarios sinceros, positivos con adecuadas expresiones faciales para potenciar una buena disposición del niño a colaborar. ${ }^{1}$ También brindará, dentro 
de sus posibilidades, apoyo y contención psicológica, emocional y afectiva a la angustia del niño y de sus padres. ${ }^{7-8}$

Se darán citas reducidas, tomando en cuenta la cantidad de pacientes que se puedan atender. ${ }^{1}$ Deben planificarse intervalos adecuados entre cada paciente, para la desinfección de la clínica debido a la gran cantidad de superficies que pueden ser contaminadas, como sillones dentales, sus manijas, escupidera e instrumentos dentales después de llevar a cabo un tratamiento, ya que son posibles vías de transmisión. El Virus SARS-CoV-2 puede persistir en las superficies hasta por 72 horas, por lo que las superficies deben desinfectarse con productos químicos recomendados para eliminar el SARSCoV. . $^{2,9,10}$

La puntualidad del Odontólogo y del paciente es indispensable. En esta etapa de crisis sanitaria, el horario de llegada debe ser estricto, para evitar el contagio social y disponer el tiempo necesario para aplicar todas las medidas de bioseguridad.

La relación Odontólogo - Paciente - Padre o acompañante, lleva implícita la creación de un vínculo. En Odontopediatría se establece una triada Padre - Odontólogo Niño que es la piedra angular tanto para el tratamiento como para la mantención de la salud. Se describe como un triángulo, donde el niño ocupa el ápice. ${ }^{7,8,11}$

El odontólogo debe estar dispuesto a responder a las necesidades del niño y sus padres. Para esto la escucha activa es importante y se produce a través del lenguaje verbal y no verbal., 12

Se debe tratar de reducir la ansiedad asociada a la visita odontológica tanto de la madre o representante como del niño, en especial en este estado de pandemia. Además, se reforzará a los padres cuáles son las conductas que deben seguir para la prevención del contagio desde que salen de casa. Una de las recomendaciones es la preparación pre visita, que puede ser por correo electrónico, por una llamada telefónica o medios electrónicos (teleodontología).

En algunas ocasiones, se podrá realizar una video-llamada que puede ser útil para favorecer la actitud del niño a su visita odontológica. Además de realizar una anamnesis exhaustiva y el envío de consentimiento informado. 2, 6, 13

Los padres deben explicarle al niño los cambios que se están produciendo en cuanto a la vestimenta del odontólogo, haciendo énfasis que es para la protección de ambos, que su doctor estará vestido en una forma especial, muy divertida y que ellos también asistirán a la consulta con mascarilla. Es importante que se cumplan las leyes y reglamentaciones con respecto a la vestimenta adecuada y el uso del EPP, para proteger tanto a los pacientes como al profesional de la salud. Se le debe explicar al niño que dependiendo del tratamiento, pudiese ser vestido con cubre botas, gorro, babero y lentes, evitando atemorizarlo; puede ser útil la estrategia Decir-MostrarHacer o el modelamiento. ${ }^{7}, 14-16$

Como con cualquier técnica o procedimiento, los padres deben estar informados de la política del consultorio $\mathrm{y}$ de los riesgos y beneficios de esta política. Cada profesional puede tener el consentimiento escrito de su preferencia, tomando en cuenta las leyes de cada país en particular. Lo importante, es que éste incluya los beneficios del tratamiento o estrategia conductual utilizada, los riesgos si estos existieran y las consecuencias si no es tratado el paciente o no son utilizadas las estrategias necesarias. ${ }^{7,13}$

Por otra parte, el clínico se enfrenta con 
la decisión de permitir a los padres estar presentes o no durante la consulta, con la excepción de niños muy pequeños o con discapacidad. Aunque no hay un acuerdo general entre los Odontopediatras, que establezca si un representante debe ser aceptado o no durante el tratamiento odontológico, existe una tendencia actual que muestra un aumento de la participación parental en la toma de decisiones, consentimiento y suministro de tratamiento. Tener a los padres dentro de la consulta puede significar una ventaja, se aprovecha la oportunidad para relacionarse con ellos, y ellos a su vez también evalúan y desarrollan una opinión acerca del trabajo y trato afectivo. Sin embargo, cuando los padres no pueden brindar un apoyo efectivo, es recomendable que permanezcan en la sala de espera. Durante la etapa de confinamiento, debe tomarse en cuenta el real aporte de la presencia del padre a que el tratamiento sea más eficaz. 7,15 En caso de que el representante ingrese al consultorio, este deberá permanecer con su mascarilla colocada.

El objetivo es brindar siempre una bienvenida cálida al paciente y sus padres, en un ambiente amistoso para el niño, disminuyendo la ansiedad y facilitando la relación Odontólogo-Paciente-Padres, aun en las situaciones diferentes derivadas de la pandemia COVID-19.

\section{Características de la vestimenta del odontólogo ajustadas con las normas de bioseguridad durante la Pandemia COVID-19:}

La vestimenta del Odontólogo ha cambiado en la actualidad. Los profesionales de la salud se visten con uniformes de variados colores, diseños y estilos; a diferencia de los uniformes tradicionales (batas blancas o unicolores). Estos uniformes más coloridos, han mostrado ser cómodos y permiten un rango mayor de movimientos. No obstante, muchos profesionales continúan prefiriendo la bata blanca, por su contenido simbólico que imprime respeto y seriedad. ${ }^{7,16}$

La vestimenta del Odontólogo en la pandemia COVID-19 cubre más el cuerpo, pudiendo incluir escafandras (overol, "bunny suit"), vestidos largos, batas y delantales. ${ }^{9,17}$

Se debe utilizar el respirador N95 o máscara quirúrgica y protección para los ojos con protectores laterales sólidos o un protector facial para proteger la mucosa, membranas de los ojos, la nariz y la boca durante los procedimientos que pueden generar salpicaduras o gotículas de saliva, sangre $\mathrm{u}$ otros fluidos corporales. ${ }^{9}$

Durante los procedimientos que generen aerosoles, se utilizará un respirador N95 o un respirador que ofrezca un mayor nivel de protección, como otros respiradores desechables con máscara filtrante. Si no hay un respirador disponible para un procedimiento de generación de aerosol, se debe utilizar una máscara quirúrgica y un protector facial completo. ${ }^{18,19}$

La vestimenta del odontólogo para la atención odontológica durante la pandemia COVID-19, puede interferir la comunicación efectiva con el paciente y el representante, por lo que se debe utilizar un tono de voz entusiasta, y potenciarse la empatía a través de la mirada. La comunicación con el niño es la clave real de un buen comportamiento y el contacto visual contribuye a la comunicación y a disminuir la ansiedad. Para ello pueden utilizarse los videos preparados por ALOP con cuentos que acercan al niño a esta nueva realidad de atención. 
Características del consultorio ajustadas con las normas de bioseguridad durante la Pandemia COVID-19:

La sala de espera desempeña una función muy importante para la primera impresión. Debe ser iluminada, con colores claros. Está claramente determinado que una clínica decorada, con carteles o cuadros, juegos y una decoración simple disminuye la ansiedad a la consulta. Igualmente, la ansiedad preoperatoria, se reduce cuando los niños participan en actividades lúdicas en el área de espera, ayudando al niño a relajarse, además de actuar como facilitador para la interacción y comunicación entre profesionales de la salud, niños y sus acompañantes. ${ }^{7,20}$

Sin embargo, durante período de pandemia, se deben retirar las revistas, flores, juguetes, peluches (juguetes de felpa), cuentos y otros elementos que puedan favorecer a la contaminación. ${ }^{21}$

Los padres deben conocer esto de antemano, para poder explicarle y preparar al niño ya que estos cambios pueden afectar la forma en que el niño percibe la ambientación de la clínica, generando una mayor ansiedad. Puede usarse la música, para relajar el paciente. Por otra parte, se recomienda traer a la consulta solo los objetos indispensables. ${ }^{7,22}$

El sanitario de la clínica dental deberá estar habilitado para su uso, con toallas de papel para el secado de manos y jabón antibacterial. Este espacio debe desinfectarse con frecuencia.

El personal auxiliar y la secretaria deben tener iniciativa para manejar situaciones difíciles, deben estar entrenadas para ofrecer el material de desinfección a usar y saber las indicaciones de cada uno. ${ }^{19}$

Es recomendable que para el área de tratamiento, se utilice luz natural, una buena iluminación y una adecuada ventilación al trabajar, evitar recorrer distancias, utilizar muebles, gabinetes ordenados y limpios, de fácil acceso a todos los materiales. ${ }^{7}$ Más aún, durante esta etapa crítica, todo lo que se va a utilizar debe ser colocado en la bandeja de la unidad dental, al momento de ser requerido, evitando el uso de recipientes y dispensadores que contribuyan a la contaminación.

\section{Estrategias para lograr la colaboración del paciente durante la consulta de Odontopediatría}

El Odontólogo debe utilizar todas aquellas estrategias efectivas para lograr la ambientación a la atención odontológica. La comunicación con el paciente es la clave para un buen comportamiento. ${ }^{7,23,24}$

El contacto visual contribuye a la comunicación y debe ser aún más utilizada en esta etapa, pues lo único que verán al odontólogo serán sus ojos. Así mismo, el tono de la voz es de gran importancia, el cual debe ser tranquilizador y entusiasta. 7,25

La comunicación no verbal es ampliamente aceptada como más influyente que la comunicación verbal. Sin embargo, los pacientes en odontopediatría interpretan tanto los mensajes verbales y no verbales. Estos mensajes no verbales se envían a travésdeuna variedad decomportamientos que incluyen la apariencia del odontólogo, sus movimientos corporales, faciales y oculares. La cara y los ojos son fuentes primarias de información emocional para los pacientes. ${ }^{12,16}$

El Odontólogo debe observar y oír al paciente a fin de detectar sus miedos, en especial a los virus, ya que puede tener miedo al contagio. Se le debe dar la oportunidad de expresar sus sentimientos. Igualmente, preguntar sus dudas $\mathrm{y}$ 
asegurarle que se está protegiendo tanto a él como al personal del consultorio para evitar el contagio. El Odontólogo debe brindarle apoyo y seguridad en todo momento, debe estar atento a las expresiones faciales y corporales que denoten miedo: ojos cerrados con fuerza, temblor del mentón, puños cerrados, entre otros. Así debe fomentar una comunicación efectiva con el niño. 7,8,26

Durante la consulta, el Odontopediatra se podrá valer del juego para adaptar al niño y ayudarlo en su proceso de aprendizaje. La ludoterapia será de gran ayuda en la situación actual, pues los niños son fantasiosos y pueden ser introducidos en este mundo mágico, siempre acorde a sus intereses y edad. ${ }^{7}$

Esto se ejemplifica en los cuentos propuestos en el anexo, para que los pacientes se acostumbren a las nuevas formas de atención odontológica por motivo del COVID-19. (Anexos 1-9)

El niño también podría llevar su juguete preferido, en una bolsa plástica de cierre fácil. Mediante el juego el niño se libera de emociones, miedo, ansiedad, rabia y hasta violencia. La ansiedad y miedo al odontólogo pueden influir en la atención y el tratamiento, llegando a convertirse en verdaderos problemas de salud bucal. Algunos estudios señalan que las niñas son más ansiosas y manifiestan mayor miedo que lo niños, pero de forma poco significativa y que depende más que todo de la madurez psicológica del niño. ${ }^{27}$

Estudios han demostrado que la estrategia Decir- Mostrar- Hacer y la distracción auditiva visual, (uso de videos) tienen la misma eficacia para realizar el acondicionamiento en los niños antes de realizar cualquier tipo de tratamiento odontológico. ${ }^{28}$

La estrategia Decir-Mostrar-Hacer, es la técnica de desensibilización enfocada de otra manera por Addelston, es muy útil en odontología tanto en la prevención del desarrollo de temores odontológicos en las primeras experiencias como en la minimización de la ansiedad y la mala conducta asociada, en el paciente previamente sensibilizado. Ha sido muy aceptada tanto por los Odontopediatras como por los padres del paciente. El odontólogo puede reducir el temor, primero "Diciéndole" al niño sobre la nueva situación, lo que va a sentir y lo que debehacer, luego "Mostrándole" el nuevo ambiente, elemento o procedimientos que van a ser realizados y finalmente, "Haciendo" lo que se le dijo que se haría. Este proceso deberá ser continuo desde la entrada del niño al consultorio a través de todos los procedimientos involucrados en el tratamiento, para orientar al niño gradualmente a los estímulos que provocan ansiedad, de manera tal que sea capaz de enfrentar la situación. La explicaciones de los procedimientos deben realizarse con lenguaje apropiado de acuerdo con el desarrollo del paciente (decir), demostrar al paciente con aspectos visuales, táctiles, auditivos y olfativos si lo amerita, el procedimiento que se va a realizar (mostrar). Es importante mostrar de una manera no atemorizante. $\mathrm{Y}$ por último concluir el procedimiento (hacer). 7, 27, 28

Durante la consulta odontopediátrica tradicionalmente se ha incluido un tiempo para la utilización de la estrategia de Decir-Mostrar Hacer, pero la utilización previa de videos o cuentos permitiría preparar al paciente para la utilización de diferentes equipos y tratamientos. Esto puede disminuir el tiempo de consulta y optimizar la realización del tratamiento. ${ }^{22}$

Otra estrategia ampliamente utilizada en Odontopediatría es el modelamiento o también llamado aprendizaje por imitación al cambio de comportamiento, 
que resulta de la observación de otro individuo. La estrategia del modelamiento se basa en que muchas respuestas de la conducta humana son imitadas y que una persona no tiene que sufrir una experiencia para saber cómo actuar y cuáles serán las consecuencias de una determinada conducta. La observación atenta por parte del paciente es primordial, y esta puede ser la verdadera situación del tratamiento o a través de películas o videos. De esta manera cuando al paciente le llegue el momento de vivir la experiencia, sabrá que esperar y así imitará las conductas que ha observado., 28 Sin embargo, durante la pandemia COVID-19 es una recomendación estricta evitar la coincidencia de personas en el consultorio, imposibilitando el modelamiento de forma presencial. Siendo así, el uso de videos $\mathrm{u}$ otro material audiovisual con lo que se pretende lograr igualmente un modelamiento de la conducta apropiada antes, durante y después de la consulta odontológica.

La técnica del modelamiento utilizando a alguno de los progenitores es valiosa. La eficacia de usar a la madre o al padre como modelo, dependerá de la edad y del vínculo con el progenitor. Por lo general los niños pequeños tienen un vínculo más arraigado con la madre, ya que el vínculo con el padre evoluciona con la edad. El apoyo parental es muy útil, en especial en niños de corta edad y además podría ser utilizado como recompensa y refuerzo positivo. Los padres pueden ayudarnos con la estrategia de ensayos en casa. La madre puede simular que es el Odontólogo y sentar al niño en una silla, donde le pedirá que abra su boca para ver sus dientes, reforzando el comportamiento adecuado. Pueden invertirse los roles, siendo el niño quien tome el lugar del Odontólogo. ${ }^{7}$

El reforzamiento positivo ha sido ampliamente utilizado en Odontopediatría.
La utilización de reforzadores positivos verbales y de acción, durante el proceso de la consulta, permite mantener una conducta positiva y colaboradora. ${ }^{7,24,}{ }^{25}$ Igualmente al finalizar la consulta siempre debe reforzarse su buen comportamiento por los esfuerzos realizados, sea con reforzadores verbales, o de ser posible, objetos (que sean de fácil desinfección).

Además de lograr la conducta apropiada durante la consulta, se destaca que es necesario mantener todos los hábitos que permitan permanecer sanos, indicarle las normas de higiene antes de retirarse, como lavado de manos y cara.

Los padresinfluyen en los comportamientos de salud bucal de los niños. Las sugerencias hacia los padres con el apoyo del profesional de la salud bucal en casa pueden guiar la prevención de caries sobre todo en este tiempo de pandemia. ${ }^{29}$

Debe enfatizarse en todo momento los correctos hábitos de higiene bucal, incluyendoelcepilladocon pastafluorurada y uso de seda dental, así como hábitos saludables de alimentación, disminuyendo el consumo de azucares refinados. Durante la pandemia COVID-19 todos los hábitos de higiene personal constituyen la primera línea de prevención.

Desde ALOP se ha diseñado un material de apoyo audiovisual, con base a todas las estrategias de adaptación a la consulta odontopediátrica y a las recomendaciones de bioseguridad emitidas por los organismosinternacionales, especialmente para brindar apoyo a la comunidad de las familias de pacientes latinoamericanos, y enfrentar de mejor manera la situación diferente generada por la pandemia COVID-19. Todo el material se encuentra anexo a esta publicación y es de libre acceso y uso. (Anexos 1-11, Figuras 1-4). 


\section{Autores}

Desarrollo de este artículo liderado por Alejandra Lipari Valdés (Chile), Salomon Alberto Cohen (Argentina), Rosemary Sogbe de Agell (España), Daniela Madrigal López (Costa Rica), Daniela Catalina Martínez Camus (Chile), María Gabriela Martínez Vásquez (Venezuela), Matias Rios-Erazo (Chile), como parte del Equipo Interdisciplinario COVID-19 de la Asociación Latinoamericana de Odontopediatría.

Equipo Interdisciplinario COVID-19 de la Asociación Latinoamericana de Odontopediatría:

Jenny Abanto (Brasil), Mariana Armada (Argentina), Paola Beltri (España), Marisol Carrillo Tabakman (Paraguay), Haydée Casaretto (Argentina), Jorge Luis Castillo (Perú), Mónica Gladys Cesetti (Argentina), Bertha Angélica Chávez González (Perú), Ana Claudia Rodrigues Chibinski (Brasil), Salomon Alberto Cohen (Argentina), Olga Cortés Lillo (España), Luzia Ana Da Silva de Carballo (Venezuela), Gonzalo De la Fuente Alvarez (Chile), Renée Di Nallo (Argentina), María Débora Elizabeth Dricas (Argentina), Sandra Echevarria (Brasil), Piedad Cecilia Echeverry Marin (Colombia), Laura Fedelli (Argentina), Carlos Flores-MIr (Canadá), Andrea Virgina González Carfora (Chile),
Lina María Hernández Salas (Colombia), Francisco José Hernández Restrepo (Colombia), Maria Teresa Ibañez Rodriguez (Bolivia), José Carlos Pettorossi Imparato (Brasil), Alejandra Lipari Valdés (Chile), Daniela Madrigal López (Costa Rica), Daniela Catalina Martínez Camus (Chile), María Gabriela Martínez Vásquez (Venezuela), A. Carolina Medina Díaz (Venezuela), Kelly Maria Silva Moreira (Brasil), Elías M. Morón (Estados Unidos de América), Martha Mutis (Estados Unidos de América), Camila Palma (Perú), Gladys Mabel Peña (Argentina), Adriana Pistochini (Argentina), Paloma Planells (España), Gabriel Politano (Brasil), Matias RiosErazo (Chile), Adriana Maria Rubiano Pinzon (Colombia), Karla Mayra Rezende (Brasil), Rosa Gabriela Rondón (Venezuela), Gabriela Scagnet (Argentina), Rosemary Sogbe de Agell (España), Marina Tavares Costa Nóbrega (Canadá), Jorgelina Valente (Argentina), Ernesto Venegas De Herrera (República Dominicana), Rosa Helena Wanderley Lacerda (Brasil), Ana Clara Zabala (Argentina), Gabriel Zambrano (Venezuela).

Información completa del Equipo Interdisciplinario COVID-19 de la Asociación Latinoamericana de Odontopediatría

\section{Referencias bibliográficas - Referências - References}

1. COVID-19 Dental Services Evidence Review (CoDER) Working Group. Recommendations for the re-opening of dental services: a rapid review of international sources. Version 1.1 Actualizado 7 de mayo 2020. Disponible en: https://oralhealth.cochrane.org/sites/oralhealth.cochrane.org/files/public/ uploads/covid19_dental_reopening_rapid_review_07052020.pdf

2. Mallineni SK, Innes NP, Raggio DP, Araujo MP, Robertson MD, Jayaraman J. Coronavirus disease (COVID-19): Characteristics in children and considerations for dentists providing their care. Int J Paediatr Dent. 2020; 30: 245- 250. Disponible en: https://doi.org/10.1111/ipd.12653

3. Ruta de atención para procedimientos de Odontología Pediátrica durante la etapa de confinamiento o cuarentena de la pandemia COVID-19. Rev Odontopediatría Latinoam. 2020; 10 (2): Disponible en: https://www.revistaodontopediatria.org/ediciones/2020/2/art-1/.

4. Organización Mundial de la Salud OMS. Vías de transmisión del virus de la COVID-19: repercusiones para las recomendaciones relativas a las precauciones en materia de prevención y control de las infecciones. 29 de marzo 2020. Disponible en: https://www.who.int/es/news-room/commentaries/ detail/modes-of-transmission-of-virus-causing-covid-19-implications-for-ipc-precaution-recommendations.

5. American Academy of Pediatric Dentistry AAPD. Re-emergence pediatric dentistry. Practice checklist. Disponible en: https://www.aapd.org/about/about-aapd/news-room/checklist/

6. Klatchoian DA, Noronha JC, de Toledo OA. Adaptación del comportamiento del paciente odontopediátrico. Manual de Referencia para Procedimientos en Odontopediatría. Asociación Latinoamericana de Odontopediatría.[Internet]Segunda Edición (5) 25-36 Disponible en https://www.revistaodontopediatria.org/publicaciones/manuales/referencia-para-procedimientos-en-odontopediatria-2da-edicion/Manual-de-Referencia-para-Procedimientos-en-Odontopediatria-2da-edicion-Capitulo-5.pdf 
7. Asociación Latinoamericana de Odontopediatría, Aime de Bilbao A, Figueroa de Garzón M, Sogbe de Agell R. Estrategias Psicoconductuales en la atención odontopediátrica. 2020 . En publicación.

8. Fodor A, De la Parra G. La relación paciente/Odontólogo: Algunas Consideraciones. Revist Dent de Chile. 2007; 99 (3) 21-26. Disponible en: https://anaservellonsemiologia.files.wordpress.com/2013/08/ la-relacion-odontologo-paciente.pdf

9. American Dental Association ADA. Interim Guidance for Minimizing Risk of COVID-19 Transmission. 2020. Disponible en: https://www.ada.org/ /media/CPS/Files/COVID/ADA_COVID_Int_Guidance_Treat_Pts.pdf

10. Mallineni SK, Innes NP, Raggio DP, Araujo MP, Robertson MD, Jayaraman J. Coronavirus Disease (COVID-19): Characteristics in children and considerations for dentists providing their care. Int J Paed Dent. [Internet] abril 2020: Disponible en: https://doi.org/10.1111/ipd.12653

11. Gedam K, Katre A. Scenario-Based Assessment of Children and Parents Preferences towards a Paediatric Dental Setup - An Observational Study. J Dent Med Sci. 2018; 17 (2): 32-42. Disponible en: https://www.iosrjournals.org/iosr-jdms/papers/Vol17-issue2/Version-1/I1702013242.pdf

12. Freeman R. A psychodynamic understanding of the dentist-patient interaction. Brit Dent J. 1999; 186 (10): 503-506. Disponible en: https://pubmed.ncbi.nlm.nih.gov/10379083/

13. Asociación Latinoamericana de Odontopediatría ALOP. Modelos de Consentimiento Informado para la Atención de Urgencias en tiempos de COVID-19. [Internet]abril 4, 2020. Disponible en: https:// www.alopodontopediatria.org/noticias/consentimiento-informado-indicados-especialmente-atenci\%C3\%B3n-emergencias-odontologicas/.

14. McHayleh N, Harfouche A, Souaid P. Techniques for managing behavior in pediatric dentistry: Comparative study of live modelling and Tell-Show-Do Based on Children's Heart Rates During Treatment. J Can Dent Assoc. 2009; 75(4): 283. Disponible en: http://www.cda-adc.ca/jcda/vol-75/ issue-4/283.html

15. Nathan JE. Eliminating pediatric behavior management problems at the outset: inviting parents into the dental operatory. J Clin Dentistry Oral Health. 2017;1(1):3-5. doi: 10.35841/oral-health.1.1.1-5

16. Alsarheed M. Children's Perception of Their Dentists. Eur J Dent. 2011; 5(2): 186-190.

17. Verbeek J, Rajamaki B, Ijaz S, Sauni R, Toomey E, Blackwood B, Tikka C, Ruotsalainen J, KilincBalci F. Personal protective equipment for preventing highly infectious diseases due to exposure to contaminated body fluids in healthcare staff. Coch Data Syst Rev. 2020; 4: CD011621. Disponible en: https:// www.cochranelibrary.com/cdsr/doi/10.1002/14651858.CD011621.pub4/epdf/full.

18. Peng X, Xu X, Li Y, Cheng L, Zhou X, Ren B. Transmission routes of 2019-nCoV and controls in dental practice. Int J Oral Sci. 2020; 12: 9. Disponible en: https://www.nature.com/articles/s41368-020-00759.pdf

19. American Academy of Pediatric Dentistry. COVID-19 Update/Coronavirus Update. Abril 2020. Disponible en: https://www.aapd.org/about/about-aapd/news-room/covid-19/

20. Shapiro M, Melmed RN, Sgan-Cohen HD, Eli I, Parush S. Behavioural and physiological effect of dental environment sensory adaptation on children's dental anxiety. Eur J Oral Sci. 2007; 115(6): 479-483. doi:10.1111/j.1600-0722.2007.00490.x

21. American Dental Association ADA. Interim Guidance for Minimizing Risk of COVID-19 Transmission. 2020. Disponible en: https://www.ada.org/ /media/CPS/Files/COVID/ADA_COVID_Int_Guidance_Treat_Pts.pdf

22. Alarco-Cadillo L, Casas L, Reyes M, Ramírez MC. Uso de dos técnicas alternativas de manejo de conducta: musicoterapia y distracción audiovisual, en el control y manejo de ansiedad en pacientes pediátricos de 5 a 10 años. Rev Odontopediatría Latinoam. 2017; 7 (1): Disponible en: https://www. revistaodontopediatria.org/ediciones/2017/1/art-3/

23. American Academy of Pediatric Dentistry. Behavior Guidance for the Pediatric Dental Patient. The Reference Manual of Pediatric Dentistry.2019-2020: 266-279. Disponible en: https://www.aapd.org/ about/about-aapd/news-room/covid-19/. 
24. Wright GZ, Starkey PE, Gardner DE. Managing children's behavior in the dental office. Toronto. Mosby Company. 1983.

25. Ripa WL, Barenie JT. Manejo de la conducta odontológica del niño. Argentina: MundiSaic y F; 1984.

26. Nash DA. Engaging children's cooperation in the dental environment through effective communication. Pediatr Dent. 2006; 28(5): 455-459.

27. Sias Salas SS, Ayala Escandón CL, Pichardo Solís VA. El dibujo como medio de evaluación del miedo/ ansiedad en niños de 5 a 8 años en atención dental. Estudio descriptivo. Rev Odontopediatría Latinoam. 2018; 8 (2): Disponible en: https://www.revistaodontopediatria.org/ediciones/2018/2/art-8/

28. Loayza S, Azanza S. Eficacia de dos técnicas de acondicionamiento para la atención odontológica de niños de 6 a 10 años de edad de una escuela pública de Quito-Ecuador. Rev Odontopediatría Latinoam. 2017; 7 (2) Disponible en: https://www.revistaodontopediatria.org/ediciones/2017/2/art-4/

29. Duijster D, De Jong-Lenters M, Verrips E, van Loveren C. Establishing oral health promoting behaviours in children - parents' views on barriers, facilitators and professional support: a qualitative study. BMC Oral Health. 2015; 15: 157. Disponible en: https:/www.ncbi.nlm.nih.gov/pmc/articles/ PMC4676163/

Recibido: 24/05/2020

Aceptado: 07/06/2020

Correspondencia: e-mail: editor@revistaodontopediatria.org 
$\underline{\text { Anexo } 1}$

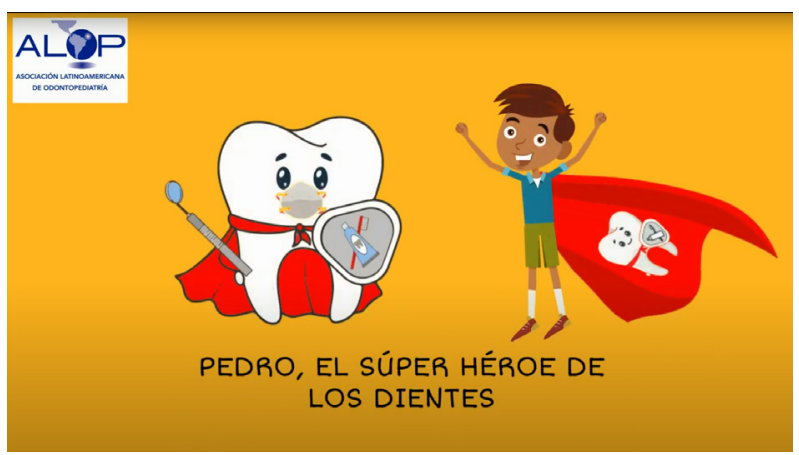

$\underline{\text { Anexo } 3}$

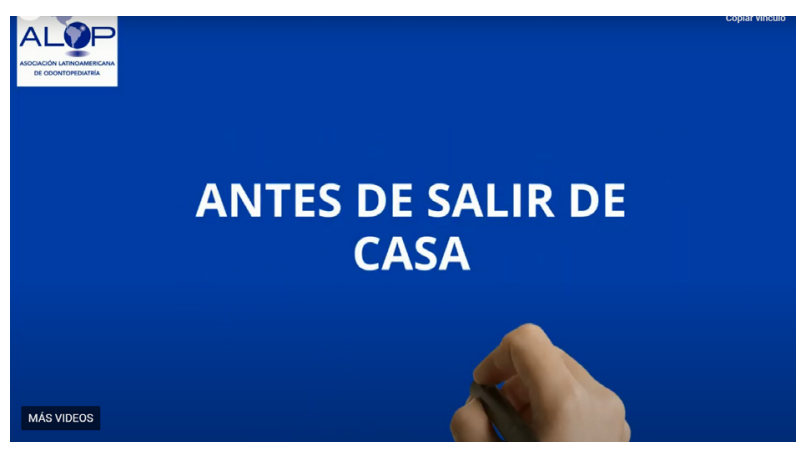

Anexo 2

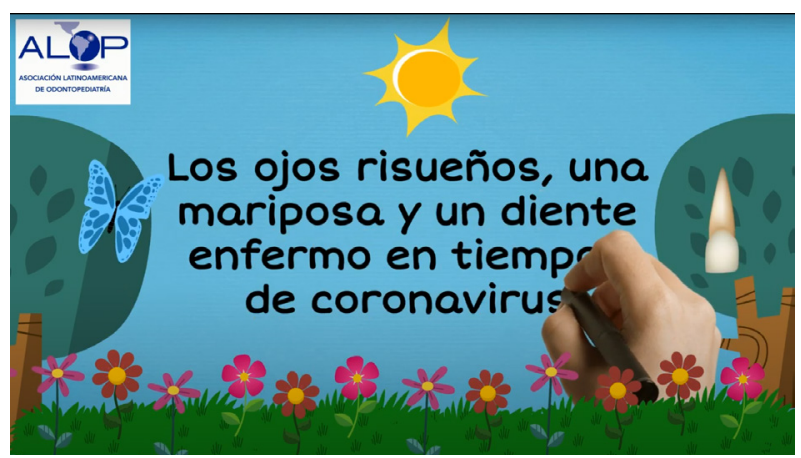

Anexo 4

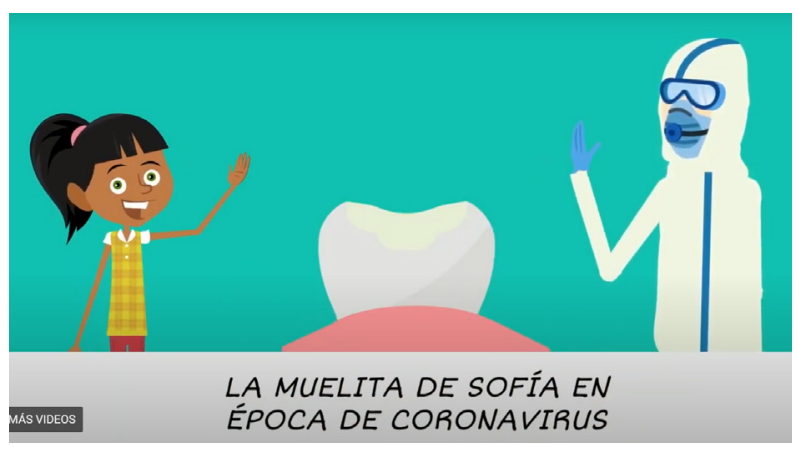

Anexo 5

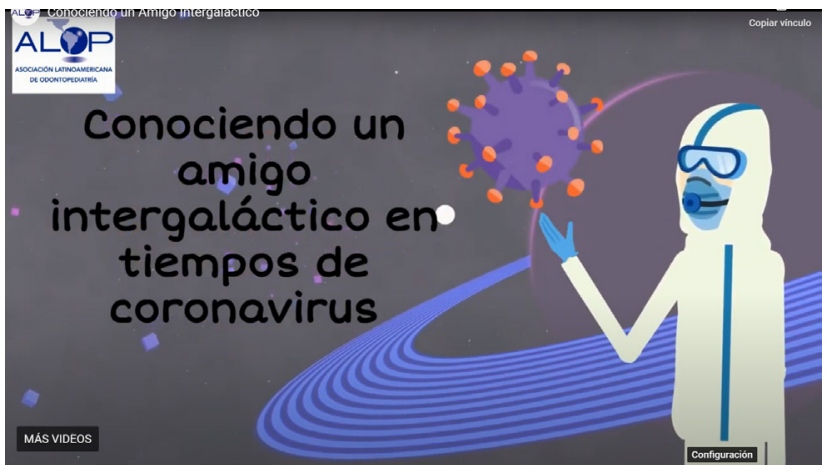




\section{$\underline{\text { Anexo } 6}$}

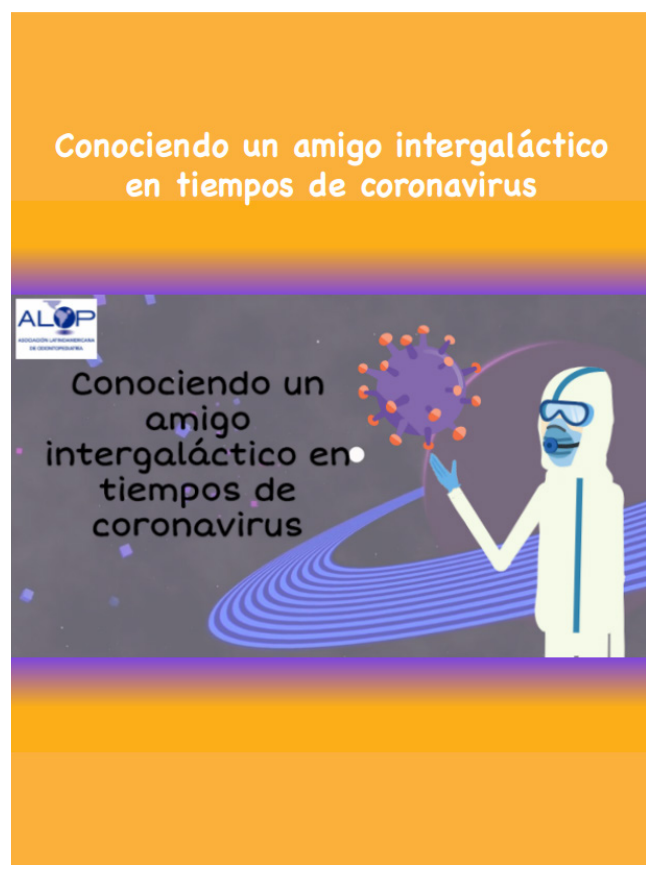

$\underline{\text { Anexo } 8}$

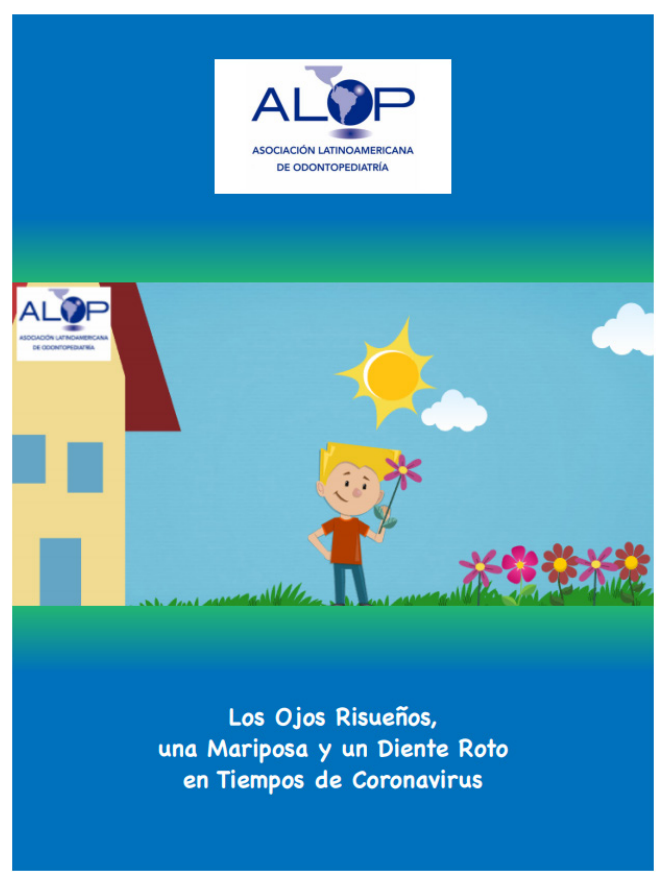

$\underline{\text { Anexo } 7}$

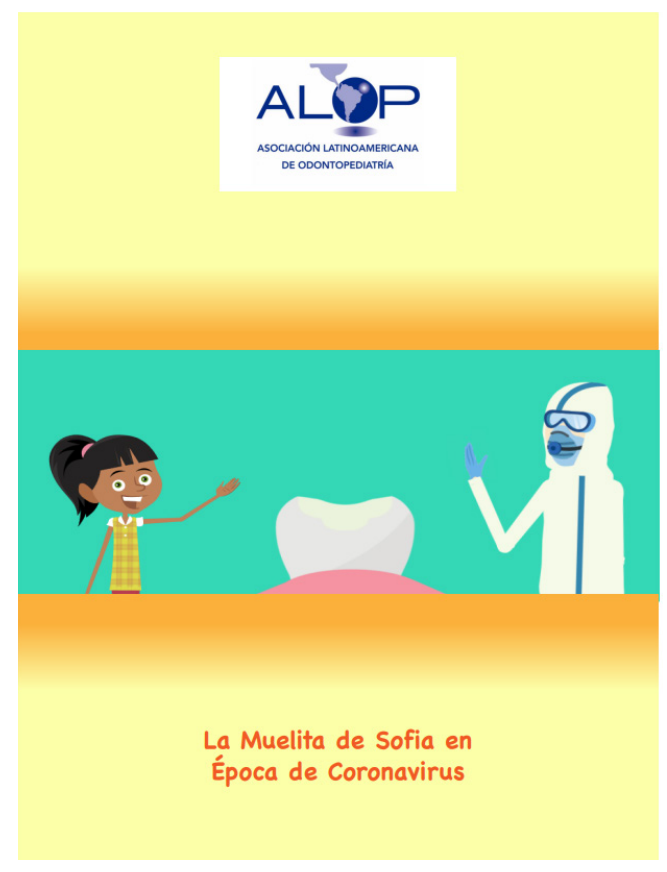

Anexo 9

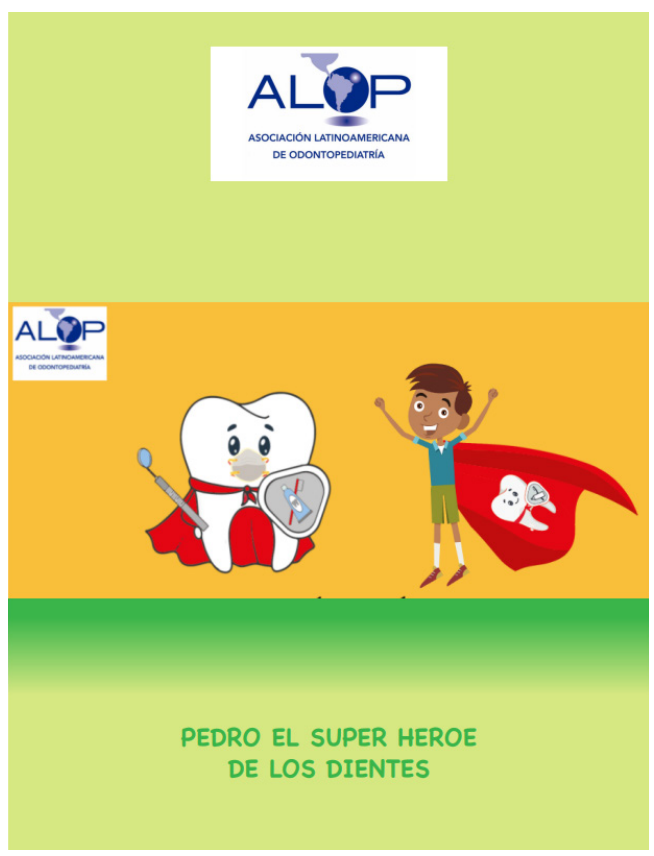


Anexo 10

\title{
ALQP ASOCIACIÓN LATINOAMERICANA DE ODONTOPEDIATRÍA
}

\author{
LISTA DE COMPROBACIÓN PARA ACUDIR A LA CONSULTA DE \\ ODONTOPEDIATRÍA DURANTE LA PANDEMIA COVID-19
}

Dirigido a madres, padres, tutores y grupo familiar de pacientes que requieran desplazarse a la consulta para tratamiento odontológico. Considera que existen diferentes etapas de confinamiento, dependiendo de la evolución de la pandemia COVID-19 en cada país. Estas medidas pueden variar con el tiempo y dependen de las regulaciones y restricciones locales. Consulta cualquier duda con tu Odontopediatra.

\begin{tabular}{|c|c|c|}
\hline \multicolumn{3}{|l|}{ ANTES DE SALIR DE CASA } \\
\hline Realiza teleconsulta /por teléfono - redes sociales / teleodontología & $\square \mathrm{SI}$ & $\square \mathrm{NO}$ \\
\hline Envía fotos o vídeos al Odontopediatra & $\square$ SI & $\square \mathrm{NO}$ \\
\hline Prepara al paciente de forma positiva antes de la consulta (cuentos, videos, ambientación) & $\square$ SI & $\square \mathrm{NO}$ \\
\hline $\begin{array}{l}\text { Mide la temperatura corporal (debe ser menor a } 37.5^{\circ} \mathrm{C} \text { ) } \\
\text { Si es mayor suspenda la cita y consulte a su médico }\end{array}$ & $\square \mathrm{SI}$ & $\square \mathrm{NO}$ \\
\hline Usa ropa cómoda & $\square \mathrm{SI}$ & $\square \mathrm{NO}$ \\
\hline $\begin{array}{l}\text { Lleva solo lo indispensable, incluyendo bolígrafo personal y bolsitas plásticas para colocar } \\
\text { mascarilla, teléfono u otros objetos }\end{array}$ & $\square \mathrm{SI}$ & $\square \mathrm{NO}$ \\
\hline 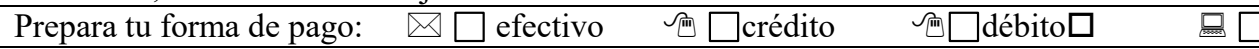 & ransfer & ncia \\
\hline Realiza higiene oral de tu hijo & $\square$ SI & $\square \mathrm{NO}$ \\
\hline Usen mascarilla durante el traslado al consultorio (paciente y acompañante) & $\square \mathrm{SI}$ & $\square \mathrm{NO}$ \\
\hline $\begin{array}{l}\text { Trasládense directo a la consulta, preferiblemente de forma particular, siguiendo las normas } \\
\text { de cada país. }\end{array}$ & $\square \mathrm{SI}$ & $\square \mathrm{NO}$ \\
\hline \multicolumn{3}{|l|}{ AL LLEGAR AL CONSULTORIO } \\
\hline Mantengan la mascarilla colocada en todo momento & SI & $\square \mathrm{NO}$ \\
\hline Puede haber limpieza de zapatos, tapete con hipoclorito o uso de polainas descartables & SI & $\mathrm{NO}$ \\
\hline Le realizan medición de temperatura corporal con escáner $\left(<\mathrm{a} 37,5^{\circ} \mathrm{C}\right)$ & SI & $\square \mathrm{NO}$ \\
\hline Guarda el teléfono celular higienizado & $\square \mathrm{SI}$ & $\square \mathrm{NO}$ \\
\hline Si vinieron con guantes, los retiran y desechan & $\square$ SI & $\square \mathrm{NO}$ \\
\hline Realizan higiene de manos & SI & $\square \mathrm{NO}$ \\
\hline Lava de la cara del paciente & $\square$ SI & $\square \mathrm{NO}$ \\
\hline Puede colocarse vestimenta especial al con bata, babero y gorro & $\square \mathrm{SI}$ & \\
\hline \multicolumn{3}{|l|}{ DURANTE LA CONSULTA } \\
\hline Acompañante espera fuera del box dental & $\square \mathrm{SI}$ & $\square \mathrm{NO}$ \\
\hline Acompañante apoya dentro del box dental (en casos excepcionales) & $\square \mathrm{SI}$ & $\square \mathrm{NO}$ \\
\hline Realiza enjuague del paciente con solución desinfectante antes de comenzar el tratamiento & $\mathrm{SI}$ & $\square \mathrm{NO}$ \\
\hline El paciente mantiene colaboración apropiada para la realización del tratamiento & SI & $\square \mathrm{NO}$ \\
\hline Al finalizar la consulta, realiza higiene de manos y cara del paciente & $\square \mathrm{SI}$ & $\square \mathrm{NO}$ \\
\hline Coloca la mascarilla en paciente y acompañante para salida del consultorio & $\square \mathrm{SI}$ & $\square \mathrm{NO}$ \\
\hline \multicolumn{3}{|l|}{ AL LLEGAR A CASA } \\
\hline Dejan zapatos en la entrada del hogar & $\square \mathrm{SI}$ & $\square \mathrm{NO}$ \\
\hline Retiran mascarillas & $\square$ SI & \\
\hline Realizan higiene de manos y cara & $\square \mathrm{SI}$ & \\
\hline Idealmente realizan baño con lavado de cabello y cambio de ropa & $\square \mathrm{SI}$ & \\
\hline Cumplen las indicaciones del odontólogo (recomendaciones y prescri & $\square \mathrm{SI}$ & \\
\hline Mantienen hábitos apropiados de higiene bucal & $\square \mathrm{SI}$ & $\square \mathrm{NO}$ \\
\hline
\end{tabular}

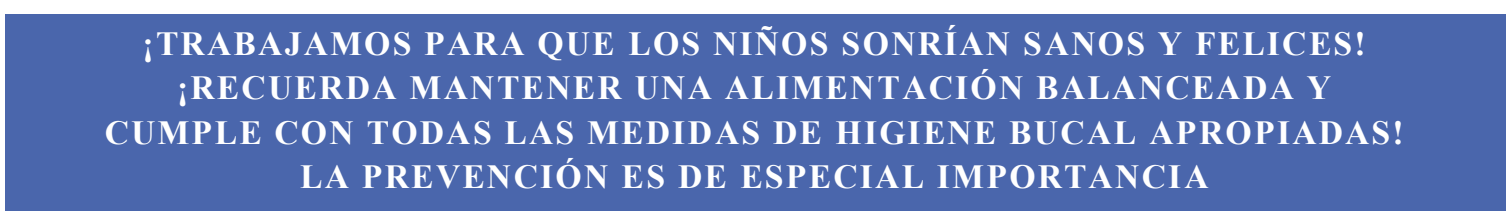


Anexo 11

\title{
ALQP ASOCIACIÓN LATINOAMERICANA DE ODONTOPEDIATRÍA
}

Cod. 608-52

\author{
INFORMACIÓN PARA PACIENTES QUE REQUIERAN PROCEDIMIENTOS DE ODONTOLOGÍA \\ PEDIÁTRICA DURANTE LA ETAPA DE LA PANDEMIA COVID-19
}

\section{ASOCIACIÓN LATINOAMERICANA DE ODONTOPEDIATRÍA}

Dirigido a padres, tutores y grupo familiar de bebés, niños, adolescentes y pacientes en situación de discapacidad, que requieran tratamiento odontológico.

\section{INTRODUCCIÓN}

Ante la situación de pandemia de COVID-19, desarrollamos el siguiente documento desde la Asociación Latinoamericana de Odontopediatría (ALOP), con el objetivo de orientar a los tutores de los pacientes sobre la atención odontológica.

\section{RELACIÓN DEL COVID-19 CON EL TRATAMIENTO ODONTOLÓGICO}

El virus de COVID-19, se transmite por el contacto directo con las gotas de la saliva que una persona infectada puede expulsar cuando habla, tose o estornuda, o al tocar superficies contaminadas por el virus. Puede sobrevivir en una superficie varias horas, pero se logra eliminar con desinfectantes comunes como agua y jabón.

Es importante tener en cuenta que las principales medidas de prevención del COVID-19 son las mismas que las de la gripe: lavarse las manos con frecuencia y cuidar la higiene respiratoria (cubrirse la boca o la nariz con el codo flexionado o con un pañuelo al toser o estornudar y desechar el pañuelo en una bolsa de basura.

En la actualidad, la pandemia presenta diferentes niveles de desarrollo en nuestros países asociados a ALOP. Hay algunos que ya han salido del aislamiento social total y han iniciado paulatinamente la atención dental y otros que aún están confinados en casa en forma total o parcial.

Es así como durante la etapa de confinamiento solo se podrá realizar tratamiento odontológico presencial en situaciones de emergencias y urgencias, para disminuir las posibilidades de contagio y reducir riesgos para los pacientes, los familiares y todo el equipo de salud.

El odontólogo pediatra u odontólogo tratante está disponible para realizar la atención telefónica o por redes (telemedicina - teleodontología) para poder brindar la mejor asesoría y propuesta de atención, según el caso que presente el paciente.

\section{¿CUÁLES SON LAS SITUACIONES DE URGENCIA ODONTOLÓGICA?}

Aunque todas las condiciones de salud bucal de su hijo son importantes, en los países en donde hay confinamiento, la atención odontopediátrica está dirigida exclusivamente a situaciones que requieran manejo inmediato para aliviar dolor, infección, hemorragia, trauma en los dientes o cara, pacientes en tratamiento de ortodoncia con algún elemento suelto, el cual corre riesgo de ingerir o aspirar o lesiones agudas en la mucosa debido a desajuste del aparato ortodóncico. En los países que ya han salido de la etapa crítica, se ha iniciado la atención odontológica con resguardos especiales. 


\title{
ALQP ASOCIACIÓN LATINOAMERICANA DE ODONTOPEDIATRÍA
}

Cod. 608-52

\author{
EN CASO DE CONFINAMIENTO EN CASA, SI MI HIJO PRESENTA DOLOR, INFLAMACIÓN, \\ TRAUMA: ¿QUÉ DEBO HACER?
}

ATENCIÓN TELEFÓNICA (TELEODONTOLOGÍA)

1- Debe contactar por vía telefónica o por redes sociales a su odontopediatra tratante. Entregue toda la información detallada, de la forma más específica, referente al motivo de consulta.

Acompañe la información con fotografías o videos que ayuden al profesional a realizar el diagnóstico.

2- Atención: El odontopediatra realizará el diagnóstico de acuerdo con la información entregada y lo orientará vía telefónica o por redes, la posibilidad de tratamiento de los síntomas, toma de medicamentos y medidas tranquilizantes que se puedan realizar en casa.

Usted tiene la responsabilidad de cumplir de forma adecuada con todas las indicaciones que reciba.

El manejo de la urgencia se realizará con el objetivo de disminuir los síntomas del paciente, además se coordinará seguimiento a distancia mediante telemedicina, hasta que el confinamiento sea levantado, culmine la cuarentena y se puedan tomar otras medidas terapéuticas.

3- Si su odontólogo determina que es necesario realizar la atención de urgencia odontológica, es imperativo que usted proporcione al odontopediatra la información verdadera referente a exposición o padecimiento de COVID-19 del niño, de usted o de cualquier miembro de su grupo familiar. Esto incluye indicar si el niño, usted o algún miembro de su grupo familiar ha tenido fiebre o problemas respiratorios como pérdida de olfato y gusto durante los últimos 14 días, si han viajado a países de riesgo o si tiene o ha tenido contacto con alguien con diagnóstico confirmado de COVID19.

Si hay sospecha de exposición, contagio o enfermedad COVID-19, debe consultar a su médico tratante y seguir el protocolo COVID-19 de sus organismos de salud previo a cualquier atención odontológica. Solo una vez. autorizado por el médico puede recibir tratamiento odontológico presencial.

4- $\quad$ Si el equipo de salud determina que es momento de realizar la atención odontológica de urgencia, el primer paso consiste en ejecutar apropiadamente, de forma escrita o digital, el consentimiento informado que su profesional le enviará. Este paso es previo a cualquier desplazamiento por parte de usted o del odontólogo al lugar de la consulta.

\section{CITA PARA TRATAMIENTO DE URGENCIA-EMERGENCIA}

Si su hijo requiere atención que no pueda ser postergada, todas las personas involucradas deben cumplir con medidas que minimicen el contagio. Esto es responsabilidad conjunta del equipo odontológico y del grupo familiar.

con el tratamiento. Utilice lenguaje adecuado que permita calmarlo, darle confianza y que no le genere miedo ni ansiedad ante el tratamiento odontológico. Si la situación lo amerita muéstrele los cuentos en video para ambientarlo a la sesión odontológica.

Controle su temperatura antes de salir de su casa. Debe ser por debajo de $37.5 \mathrm{C}$, si es más alta consulte primero a su médico.

Utilice todas las medidas indicadas por las autoridades e instituciones de salud: tanto el niño como su representante deben utilizar mascarilla. Vaya directo desde su casa hasta el consultorio, sin parar en lugares públicos. No retirare las mascarillas hasta que sea indicado, al retirarlas guárdelas en una bolsa plástica. 


\section{ALQP ASOCIACIÓN LATINOAMERICANA DE ODONTOPEDIATRÍA}

Cod. 608-52

Para cumplir con el distanciamiento social, la cita será dada de forma puntual y en la sala de espera debe mantener una distancia mínima de 2 metros con otras personas. El paciente debe asistir máximo con un acompañante a la consulta. Además, en caso de ser posible es preferible que ingrese solo al consultorio dental. Las excepciones serán evaluadas junto al odontólogo tratante.

Al ingresar al consultorio deberá higienizar sus manos con alcohol gel y luego realizar el lavado de manos y cara del niño. Preferiblemente debe colocarse botas descartables sobre el calzado y gorro.

Las pertenencias personales debe dejarlas fuera del área de atención Preferiblemente debe acudir únicamente con su cartera. Los bolsos, mochilas, relojes, pulseras, zarcillos, o cualquier elemento que no sea indispensable, debe dejarlo en casa (Juegos electrónicos, pantallas, tabletas). El celular lo debe poner en SILENCIO, debe limpiarlo con alcohol en el momento del lavado de manos y guardarlo, preferiblemente en una bolsa plástica con cierre fácil.

El odontólogo y todo su equipo siguen medidas estrictas que minimizan la posibilidad de contagio por lo cual utilizarán equipo de protección personal diferente al cual usted está habituado, incluyendo mascarillas especiales, viseras, pantalla facial y vestimenta anti fluidos o descartable de diferente índole. Verifique que estas normas están siendo realizadas por el equipo que atiende a su hijo.

Puede ser que el Odontólogo lo reciba solo con mascarilla como una primera aproximación al niño y luego se vista con el resto de los elementos mencionados o en otras ocasiones lo recibirá con todos los elementos para proteger al paciente y a los profesionales de salud de contagio. Debe explicarle al niño que su odontólogo tendrá una vestimenta especial y diferente.

Antes de comenzar la atención se le indicará al niño que realice un enjuague con solución desinfectante. En caso de que su hijo no logre enjuagarse solo, se le higienizará su boca con una gasa.

Se realizará el tratamiento odontológico adecuado para eliminar el dolor, infección o hemorragia, pero utilizando técnicas que minimicen la producción de aerosoles.

Si el acompañante se encuentra en la sala de espera manténgase tranquilo y espere pacientemente a su hijo. La atención dental puede tomar más tiempo del habitual debido a que se tomaran medidas estrictas para minimizar la posibilidad de contagio. Si ingresó al box dental junto al paciente, siga las indicaciones del personal de salud dental. Mantenga su mascarilla puesta y no interfiera en la atención del paciente a menos que se le solicite.

Terminado el tratamiento, deberá realizar el lavado de manos y cara del niño y las suyas. Posteriormente deben colocar sus mascarillas nuevamente.

Para el pago de la consulta, es preferible utilizar medios electrónicos, evitando el uso de efectivo. En caso de llevar dinero, deberá contarlo usted mismo y guardarlo en una bolsa plástica. Lleve su bolígrafo personal.

Mantenga el distanciamiento social y dirigirse a su hogar. Al llegar a casa deje sus zapatos y los del paciente en la entrada. Tanto el paciente como el acompañante deben dirigirse directo al baño, retirar sus mascarillas, lavarse manos y cara. Las mascarillas deben desecharse en un recipiente cerrado al interior de una bolsa. Si son mascarillas de género, debe dejarlas en una bolsa y luego lavar aparte del resto de la ropa. Recuerde seguir las indicaciones del odontólogo referente a cuidados y toma de medicamentos. Igualmente, de hacer el seguimiento conjunto. 


\title{
ALP ASOCIACIÓN LATINOAMERICANA DE ODONTOPEDIATRÍA
}

Cod. $608-52$

\author{
CITA PARA TERMINAR TRATAMIENTOS O CONTROL, PASADO EL CONFINAMIENTO \\ SOCIAL
}

En algunos países se están iniciando las consultas odontológicas. En este caso debe mantener las medidas de resguardo. El consultorio dental estará preparado para recibirlo con las medidas necesarias de control de infección al igual que la vestimenta del odontopediatra y su equipo, que puede ser a través de bata larga, buzo, mascarillas especiales, pantalla facial, lentes protectores, gorro y lo que se defina en forma local como más apropiado.

OTRAS CONSIDERACIONES

Estime que, durante este periodo, es fácil agobiarse por todo lo que se escucha sobre la enfermedad por COVID19. También es comprensible que sus hijos estén nerviosos. Para los niños puede ser difícil entender lo que ven en internet o en la televisión, o lo que escuchan decir a otras personas, y pueden ser especialmente vulnerables a sentimientos de ansiedad, estrés y tristeza. Sin embargo, mantener una conversación abierta y sincera con sus hijos podrá ayudarlos a entender y sobrellevar la situación e incluso a realizar una contribución positiva para los demás. Los niños pueden responder al estrés de diversas formas, por ejemplo, mostrándose más dependientes, preocupados, enfadados o agitados, encerrándose en sí mismos o mojando la cama. Muéstrese comprensivo ante las reacciones de su hijo, escuche sus preocupaciones y ofrézcale más amor y atención. Cuando sea posible, organice momentos de juego y relajación con su hijo. Enséñale a protegerse a sí mismo y a sus amigos. Puede encontrar otras medidas de apoyo en diferentes medios electrónicos y páginas de apoyo de los organismos internacionales de salud. https://www.covidl 9parenting.com/spanish

Algunas formas para contribuir a frenar la propagación del COVID-19 recomendadas por la OMS:

- Sigue el protocolo adecuado al estornudar y toser: cúbrete la boca y la nariz con un codo flexionado o con un pañuelo cuando tosas o estornudes, desecha el pañuelo inmediatamente y lávate las manos.

- Evita tocarte la cara (boca, nariz y ojos).

- Pon en práctica el distanciamiento social: evita dar la mano, abrazar o besar a otras personas, así como compartir comida, utensilios, vasos y toallas.

- Evita el contacto directo con cualquier persona que presente síntomas similares a los de la gripe o el resfriado.

- Busca ayuda médica lo antes posible si tú o tu hijo tienen fiebre, tos o dificultades para respirar.

\section{CONSIDERACIONES FINALES}

Las presentes recomendaciones están basadas en la mayor evidencia científica disponible hasta la fecha, siendo el COVID-19 una enfermedad emergente. Se realizarán las actualizaciones necesarias conforme el estado de la ciencia al respecto avance.

Estas recomendaciones han sido realizadas de forma independiente y voluntaria por los investigadores de la Asociación Latinoamericana de Odontopediatría, libres de conflicto de interés.

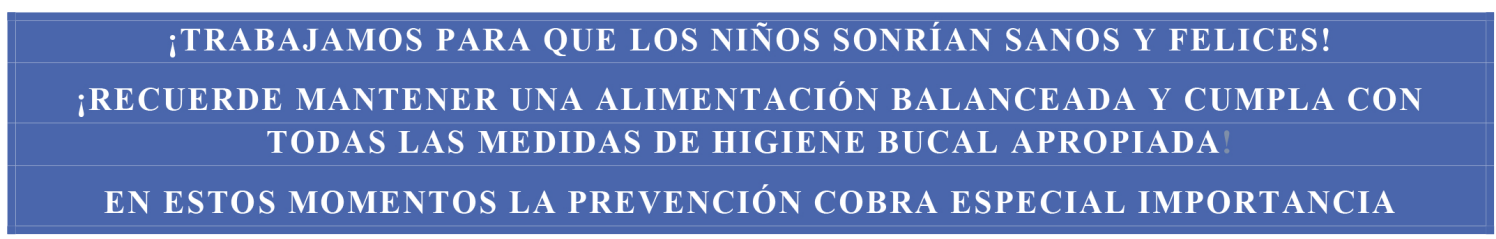




\section{ALQP ASOCIACIÓN LATINOAMERICANA DE ODONTOPEDIATRÍA}

Cod. 608-52

\section{BIBLIOGRAFÍA}

Asociación Latinoamericana de Odontopediatría, Aime de Bilbao A, Figueroa de Garzón M, Sogbe de Agell R. Estrategias Psicoconductuales en la atención odontopediátrica. 2020 . Libro en revisión por ALOP.

American Academy of pediatric dentistry. Behavior Guidance for the Pediatric Dental Patient. The Reference Manual of Pediatric Dentistry. [Internet] 2019-2020: 266-279. Disponible en: https://www.aapd.org/about/about-aapd/newsroom/covid-19/.

American Academy of Pediatric Dentistry. COVID-19 Update/Coronavirus Update. 2020 Abril. Disponible en: https://www.aapd.org/about/about-aapd/news-room/covid-19/.

American Dental Association ADA. Emergency Care. abril 2020. Disponible en: https://www.aapd.org/about/aboutaapd/news-room/emergency-care/.

American Dental Association ADA. Interim Guidance for Minimizing Risk of COVID-19 Transmission. [Internet] Chicago IL, 2020. Disponible en: https://www.ada.org/ /media/CPS/Files/COVID/ADA_COVID_Int_Guidance_Treat_Pts.pdf

American Dental Association ADA. What Constitutes a Dental Emergency?. Marzo 31, 2020. Disponible en:https://success.ada.org/ /media/CPS/Files/Open\%20Files/ADA_COVID19_Dental_Emergency_DDS.pdf?utm_sourc $\mathrm{e}=$ adaorg\&utm_medium=covid-resources-lp\&utm_content $=$ cv-pm-emerg-def\&utm_campaign $=$ covid$19 \& \_g a=2.2729136 .124928618 .1586021397-1939509346.1586021396$.

Asociación Latinoamericana de Odontopediatría ALOP. Modelos de Consentimiento Informado para la Atención de Urgencias en tiempos de COVID-19. [Internet] abril 4, 2020. Disponible en: https://www.alopodontopediatria.org/noticias/consentimiento-informado-indicados-especialmente-atenci\% $\% 3 \% \mathrm{~B} 3 \mathrm{n}$ emergencias-odontologicas/.

Asociacion Latinoamericana de Odontopediatría. Ruta de atención para procedimientos de Odontología Pediátrica durante la etapa de confinamiento o cuarentena de la pandemia COVID-19. Rev Odontopediatría Latinoam. [Internet] 2020; 10 (2): Disponible en: https://www.revistaodontopediatria.org/ediciones/2020/2/art-1/.

Centers for Disease Control and Prevention CDC. Interim Infection Prevention and Control Recommendations for Patients With Suspected or Confirmed Coronavirus Disease 2019 (Covid-19) in Healthcare Settings. abril 2020. Disponible en: https://www.cdc.gov/coronavirus/2019-ncov/hcp/infection-controlrecommendations.html?CDC_AA_refVal=https $\% 3 \mathrm{~A} \% 2 \mathrm{~F} \% 2 \mathrm{Fwww} . \mathrm{cdc}$.gov\%2Fcoronavirus $\% 2 \mathrm{~F} 2019$ ncov\%2Finfection-control\%2Fcontrol-recommendations.html .

Centers for Disease Control and Prevention CDC. Recommendation: Postpone Non-Urgent Dental Procedures, Surgeries, and Visits. Marzo 27, 2020. Disponible en: https:/www.cdc.gov/oralhealth/infectioncontrol/statement-COVID.html .

Cluver L, Lachman JM, Sherr L, Wessels I, Krug E, Rakotomalala S, Blight S, Hillis S, Bachman G, Green O, Butchart A, Tomlinson M, Ward CL, Doubt J, McDonald K. Parenting in a time of COVID-19. Lancet. 2020 Apr 11;395(10231): Disponible en:https://www.ncbi.nlm.nih.gov/pmc/articles/PMC7146667/

COVID-19 Dental Services Evidence Review (CoDER) Working Group. Recommendations for the re-opening of dental services: a rapid review of international sources. [Internet] Version 1.1 updated 7th may 2020. Disponible en: https://oralhealth.cochrane.org/sites/oralhealth.cochrane.org/files/public/uploads/covid19_dental_reopening_rapid_revie W_07052020.pdf

Harrel SK, MOLINARI J. Aerosols and splatter in dentistry A brief review of the literature and infection control implications. JADA. 2004;135:429-437. Disponible en: https://pubmed.ncbi.nlm.nih.gov/15127864/

Kampf G, Todt D, Pfaender S, Steinmann E. Persistence of coronaviruses on inanimate surfaces and their inactivation with biocidal agents. J Hosp Infect. 2020:Disponible en: https://www.journalofhospitalinfection.com/article/S01956701(20)30046-3/fulltext.

Klatchoian DA, Noronha JC, de Toledo OA. Adaptación del comportamiento del paciente odontopediátrico. Manual de Referencia para Procedimientos en Odontopediatría. Asociación Latinoamericana de Odontopediatría.[Internet] Segunda Edición (5) 25-36 Disponible en https://www.revistaodontopediatria.org/publicaciones/manuales/referencia-paraprocedimientos-en-odontopediatria-2da-edicion/Manual-de-Referencia-para-Procedimientos-en-Odontopediatria-2daedicion-Capitulo-5.pdf 


\section{ALQP ASOCIACIÓN LATINOAMERICANA DE ODONTOPEDIATRÍA}

Cod. $608-52$

Mallineni SK, Innes NP, Raggio DP, Araujo MP, Robertson MD, Jayaraman J. Coronavirus Disease (COVID-19): Characteristics in children and considerations for dentists providing their care. Int J Paed Dent. [Internet] abril 2020: Disponible en: https://doi.org/10.1111/ipd.12653

Meyer B, Casamassimo P, William F Vann, FV. An Algorithm for Managing Emergent Dental Conditions for Children Volume 43, Number 3/2019. The Journal of Clinical Pediatric Dentistry. 2019;43(3):Disponible en: https://doi.org/10.17796/10534625-43.3.10

OMS. Comité Permanente entre Organismos sobre Salud Mental y Apoyo Psicosocial en Situaciones de Emergencia (GR IASC SMAPS). Mi héroe eres tú. Un libro para los niños y niñas de todo el mundo afectados por la pandemia de COVID-19. Disponible en: https:/www.unicef.org/mexico/informes/mi-h\%C3\%A9roe-eres-t\%C3\%BA

Organización Mundial de la Salud OMS COVID-19: Materiales de comunicación. Disponible en: https://www.paho.org/es/covid-19-materiales-comunicacion

Organización Mundial de la Salud OMS. Vías de transmisión del virus de la COVID-19: repercusiones para las recomendaciones relativas a las precauciones en materia de prevención y control de las infecciones. marzo 29, 2020. Disponible en:https://www.who.int/es/news-room/commentaries/detail/modes-of-transmission-of-virus-causing-covid19-implications-for-ipc-precaution-recommendations .

Organización Mundial de la Salud OMS.Brote de enfermedad por coronavirus (COVID-19): Orientaciones para el público. Disponible en:https://www.who.int/es/emergencies/diseases/novel-coronavirus-2019/advice-for-public

Peng X, Xu X, Li Y, Cheng L, Zhou X, Ren B. Transmission routes of 2019-nCoV and controls in dental practice. Int J Oral Sci [Internet] 2020; 12:9. Disponible en: https://www.nature.com/articles/s41368-020-0075- 9.pdf

Parenting for Lifelong Health. Disponible en: https://www.covid19parenting.com/spanish.

Sabino-Silva R, Gomes Jardim AC, Siqueira WL. Coronavirus COVID-19 impacts to dentistry and potential salivary diagnosis. Clin Oral Invest. 2002;24:1619-1621. Disponible en: https:/www.ncbi.nlm.nih.gov/pmc/articles/PMC7088419/

United Nations International Children'sEmergencyFund (Unicef)Cómo hablarle a tu hijo sobre la enfermedad por coronavirus 2019 Disponible en:- HYPERLINK "https://www.unicef.org/es/coronavirus/como-hablarle-a-tu-hijo-sobre-coronaviruscovid-19" https://www.unicef.org/es/coronavirus/como-hablarle-a-tu-hijo-sobre-coronavirus-covid-19

Van Doremalen N, Bushmaker T T, Morris DH DH, Holbrook, et al. Acrosol and Surface Stability of SARS-CoV-2 as Compared with SARS-CoV-1. N Engl J Med. abril 2020; Disponible em: https:/www.nejm.org/doi/pdf/10.1056/NEJMc2004973?articleTools=true

Verbeek J, Rajamaki B, Ijaz S, Sauni R, Toomey E, Blackwood B, Tikka C, Ruotsalainen J, KilincBalci F. Personal protective equipment for preventing highly infectious diseases due to exposure to contaminated body fluids in healthcare staff. Coch Data Syst Rev [Internet] 2020;4:CD011621. Disponible en: https://www.cochranelibrary.com/cdsr/doi/10.1002/14651858.CD011621.pub4/epdf/full.

Xu H, Zhong L, Deng J, Peng J, et al. High expression of ACE2 receptor of 2019-nCoV on the epithelial cells of oral mucosa. Intl J Oral Sci. 2020;12(8):Diponible en: https://doi.org/10.1038/s41368-020-0074-x. 
INSTRUCTIVO PARA PACIENTES

Atención odontológica durante la pandemia COVID-19

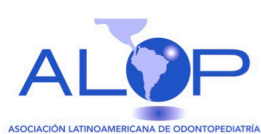

ANTES DE LA CONSULTA:
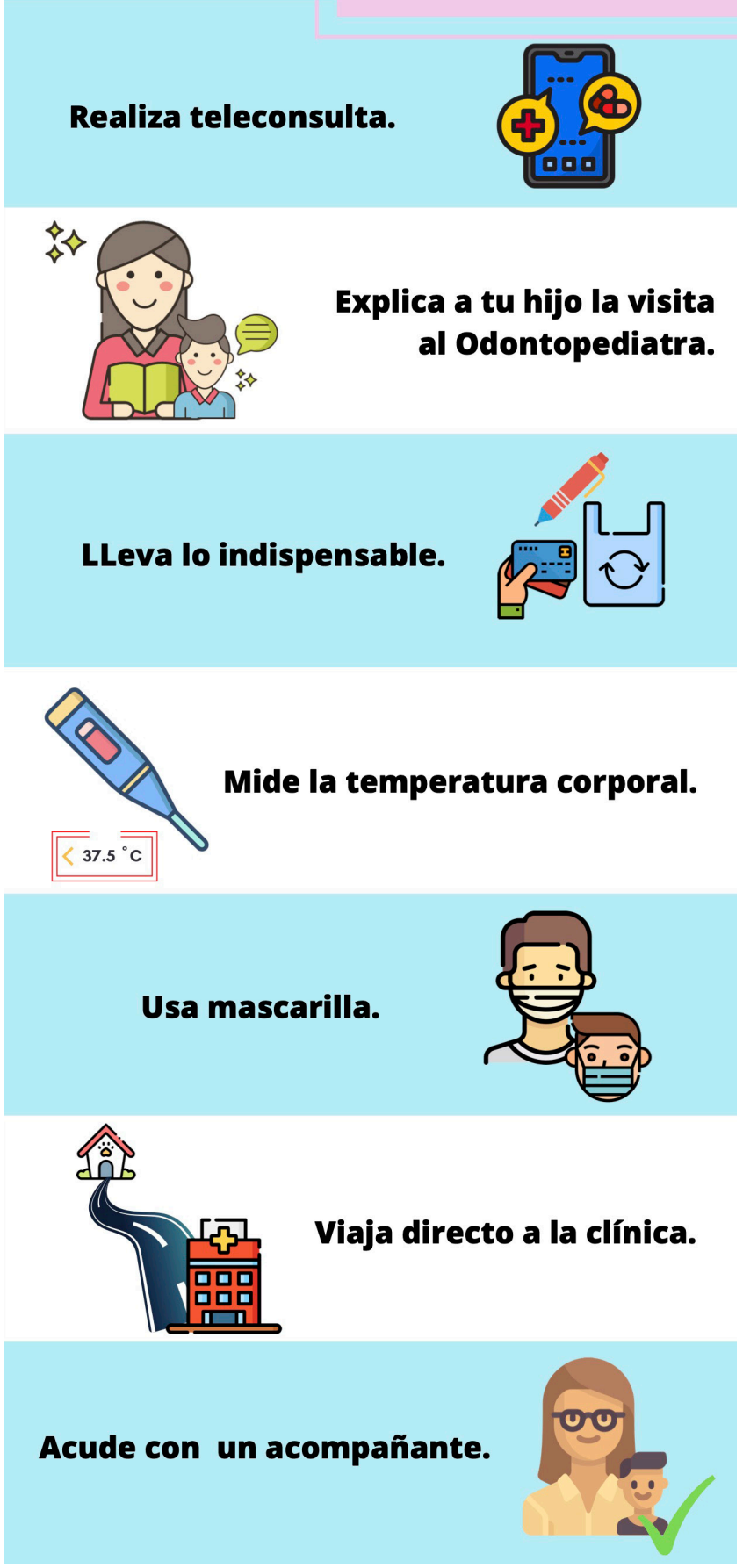

Figura 1

\section{INSTRUCTIVO PARA PACIENTES}

\section{Atención odontológica durante la pandemia COVID-19}

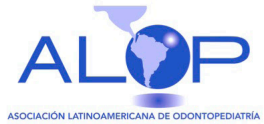

AL LLEGAR A CONSULTA:

No retires tu mascarilla.
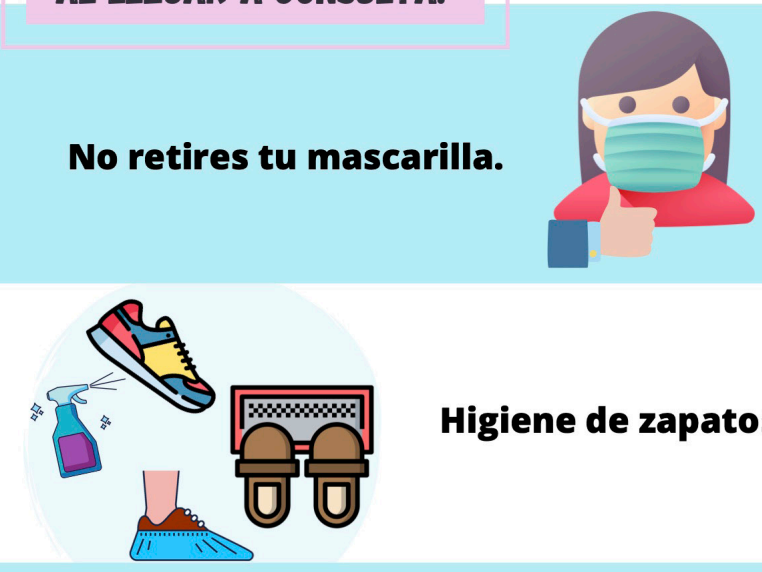

Higiene de zapatos.

Control de temperatura corporal.
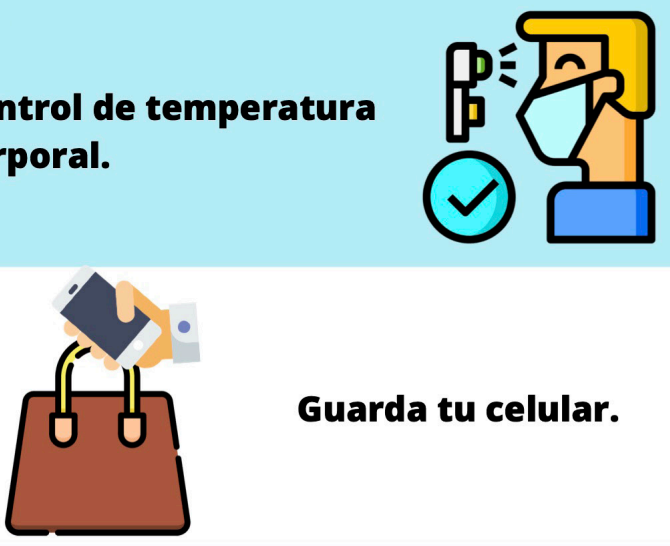

Guarda tu celular.

$$
\div-
$$

Higiene de manos y cara.
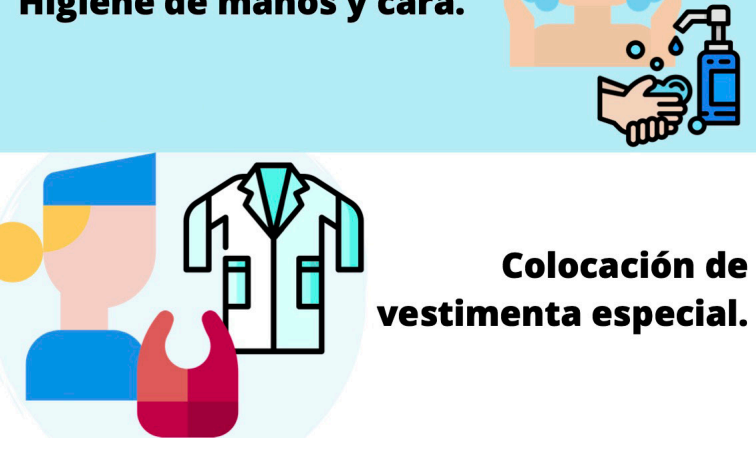

Figura 2 


\section{Atención odontológica} durante la pandemia COVID-19

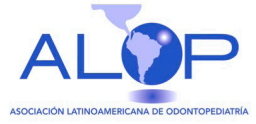

DURANTE LA ATENCIÓN:

Ingreso solo del paciente (Ideal).

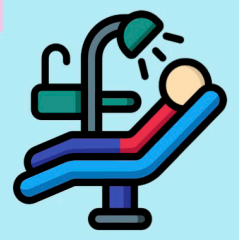

Enjuagatorio bucal.

Paciente colabora con tratamiento

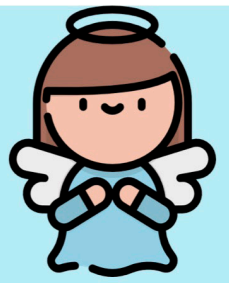

Higiene de cara.

Higiene de manos.

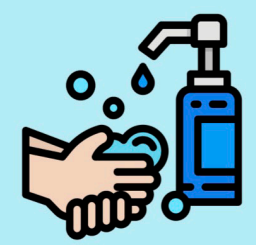

Adiós

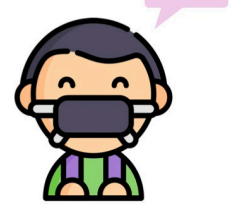

Usen mascarilla al

salir.

Figura 3

\section{Atención odontológica durante la pandemia COVID-19}

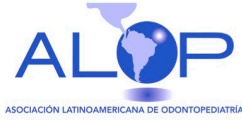

AL LLEGAR A CASA:

Zapatos en la entrada.

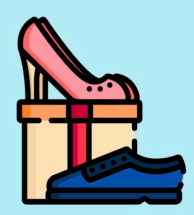

Lava tus manos.

Retira la mascarilla.

\section{$\Delta$}
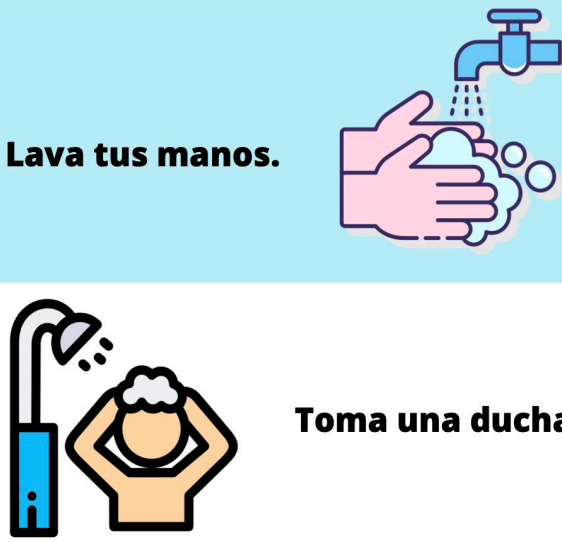

Toma una ducha.

Sigue las indicaciones del especialista.

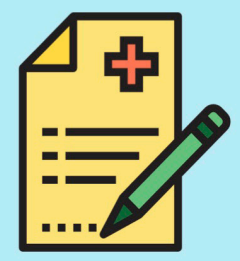

¡En estos momentos, la PREVENCIÓN es de vital importancia!

Figura 4 


\section{Estratégias e informações psicocomportamentais para dentistas e pacientes que necessitam de procedimentos de Odontopediatria durante o momento pandêmico COVID-19}

\section{Introdução}

Diante da pandemia de coronavírus, os seguintes documentos foram desenvolvidos pela Associação LatinoAmericana Odontopediatria (ALOP), para apoiar os odontopediatras, a comunidade e as famílias sobre como abordar o atendimento odontológico infantil durante o período deste crise de saúde.

A pandemia do COVID-19 levou ao fechamento de consultórios odontológicos em todo o mundo. No entanto, dependendo do estado da pandemia, atualmente, alguns países estão reabrindo ou planejam reabrir seus consultório como parte de uma saída para a estratégia de evitar a falência. Devido à necessidade urgente de um guia de tomada de decisão, esta revisão é realizada com base nas melhores evidências disponíveis. Nesta situação de pandemia em evolução, as informações fornecidas por cada país podem estar sujeitas a alterações. ${ }^{1}$

O objetivo é fornecer orientações básicas aos pais, responsáveis e grupos familiares das crianças que necessitam de tratamento odontológico durante o período da pandemia de Coronavírus. Essas medidas incluem orientações sobre mudanças na modalidade de atendimento para consultas pediátricas, gestão em casa para uma melhor convivência, medidas a serem consideradas para comparecer à consulta odontológica, antes de sair de casa, durante a viagem e retorne ao consultório odontológico e cuide-se ao voltar para casa. Essas recomendações baseiam-se nas informações científicas disponíveis até o momento, incluindo publicações e diretrizes de organizações internacionais de saúde, bem como nas publicadas pela Associação Latino-americana odontopediatria ALOP. Essas informações podem estar sujeitas a alterações futuras; portanto, é recomendável que as atualizações deste material sejam acompanhadas.

Os documentos estão escritos em uma linguagem que o torna compreensível em todos os países associados e, no caso de crianças, de maneira mais lúdica, anexando histórias escritas e em vídeo para demonstrar as novas formas de atendimento odontológico devido ao COVID-19.

No caso dos pais, foram desenvolvidos documentos para apoiar o gerenciamento desta crise do ponto de vista do ambiente familiar e também para colaborar no entendimento das medidas de controle da propagação do vírus, uma lista de verificação das atividades antes, durante $\mathrm{e}$ após a consulta odontológica, no modo de texto e vídeo.

Características da consulta odontología durante a Pandemia COVID-19

En la actualidad la pandemia COVID-19 se encuentra en diferentes grados de expresión y los países que conforman ALOP se encontrarán en distintas etapas de atención odontológica, lo que requiere una amplia gama de medidas que aplicar 
de acuerdo con las circunstancias de cada uno.

Atualmente, a pandemia do COVID-19 encontram-se em diferentes estágios em cada país que compõem o ALOP. Estão em diferentes etapas de atendimento odontológico, o que requer uma ampla gama de medidas para serem aplicadas de acordo com as circunstâncias de cada um.

Durante o atendimento odontopediatrico nas diferentes fases da pandemia, as opções de tratamento e seu planejamento podem variar. Os países implementaram medidas diferentes para a prestação geral de atendimento odontológico, mesmo durante as fases "generalizadas de infecção humana" da pandemia, levando a picos de infecção. ${ }^{2}$

Durante o estágio de confinamento ou quarentena, o atendimento odontológico deve ser realizado apenas em pacientes com emergências e urgência, e o tratamento odontológico eletivo e não essencial deve ser interrompido. Se possível, execute os cuidados de teledontologia por telefone ou usando aplicativos. Um questionamento dos sinais e sintomas da criança deve ser realizada, permitindo que uma hipótese de diagnóstico seja obtido com tratamento sintomático. $\mathrm{O}$ uso de fotos e vídeos, bem como videochamadas, pode ajudar a melhorar o diagnóstico. Se não for possível gerenciar e controlar a emergência por teleodontologia, o paciente deve ir à consulta presencial. Apenas serão tratados pacientes com: pulpite irreversível grave, pericoronarite, abscesso dentoalveolar, alveolite, hemorragia, trauma dentoalveolar com fratura dentária, avulsão ou luxação. ${ }^{3-5}$

Durante o período pandêmico do COVID-19, devem ser usadas alternativas de tratamento que usem aerossol e todas as precauções apropriadas devem ser tomadas com o uso de equipamento de proteção individual (EPI). ${ }^{3-4}$

À medida que os países passam pelas etapas mais críticas, $\mathrm{o}$ atendimento odontológico se estende a tratamentos eletivos, como primeiras consultas, tratamentos sucessivos ou controles pendentes. Nesses estágios, os protocolos mudam, mas regras especiais de controle de infecção são mantidas tanto na consulta quanto no vestuário do pessoal de saúde e do paciente. ${ }^{1-3}$

\section{Relação Dentista - Paciente - Pais}

A Odontopediatria é uma especialidade que exige muito do profissional do ponto de vista psicológico. O especialista em odontopediatrua deve ter empatia afetiva, que é a capacidade de entender os pensamentos e sentimentos do paciente e agir de maneira apropriada a ele. $\mathrm{O}$ dentista deve fazer comentários sinceros e positivos com expressões faciais apropriadas para aumentar a disposição de uma criança em colaborar. ${ }^{1}$ Ele também fornecerá, dentro de suas possibilidades, apoio psicológico, emocional e afetivo e contenção ao sofrimento da criança e de seus pais. ${ }^{7-8}$

Serão realizadas consultas reduzidas, levando em consideração o número de pacientes que podem ser tratados. ${ }^{1}$ Intervalos adequados devem ser planejados entre cada paciente, para a desinfecção da clínica devido ao grande número de superfícies que podem ser contaminadas, como cadeiras odontológicas, braços da cadeira, cuspideira e instrumentos dentários após a realização de um tratamento, pois as rotas de transmissão são possíveis. $\mathrm{O}$ vírus SARS-CoV-2 pode persistir em superfícies por até 72 horas; portanto, as superfícies 
devem ser desinfetadas com produtos químicos recomendados para remover o SARS-CoV. $2,3,9,10$

A pontualidade do dentista e do paciente é essencial. Nesta fase da crise da saúde, o horário de chegada deve ser rigoroso, para evitar o contágio social e ter o tempo necessário para aplicar todas as medidas de biossegurança.

A relação Dentista - Paciente - Pais ou responsável implica a criação de um vínculo. A Odontopediatria estabelece uma tríade de pais - dentistas - crianças que é a pedra angular do tratamento e da manutenção da saúde. É descrito como um triângulo, onde a criança ocupa o ápice. ${ }^{7,8,11}$

O dentista deve estar disposto a responder todas as dúvidas e necessidades da criança e de seus pais. Para isso, ouvir é importante e ocorre através da linguagem verbal e não verbal. ${ }^{7,12}$

Esforços devem ser feitos para reduzir a ansiedade associada a uma visita odontológica pela mãe ou responsável e pela criança, especialmente nesse momento de pandemia. Além disso, os pais serão orientados quais são as condutas que devem seguir para a prevenção de contágio desde que saem de casa. Uma das recomendações é a preparação pré-visita, que pode ser por email, telefone ou por meio eletrônico (teledontologia). ${ }^{3,6}$

Em algumas ocasiões, uma videochamada pode ser útil para promover a atitude da criança em relação à sua consulta odontológica. Além de realizar uma anamnese detalhada e enviar o consentimento informado. ${ }^{2,6,13}$

Os pais devem explicar à criança as mudanças que estão ocorrendo em termos de roupas de EPI do dentista, enfatizando que é para a proteção de ambas, e que o dentista estará com uma roupa especial, muito divertida e que eles também participarão da consulta com máscara. É importante que sejam respeitadas as leis e regulamentos relativos à roupa adequada e ao uso de EPI, para proteger pacientes e profissionais de saúde. Deve-se explicar à criança que, dependendo do tratamento, ela pode precisar colocar propé, gorro, avental e óculos, evitando assustá-la; A estratégia ou modelagem falar-mostrar e fazer pode ser útil. ${ }^{7,14-16}$

Como em qualquer técnica ou procedimento, os pais devem ser informados da política do consultório e dos riscos e benefício. Cada profissional pode ter o consentimento por escrito de sua escolha, levando em consideração as leis de cada país em particular. O importante é que ele inclua os benefícios do tratamento ou estratégia comportamental utilizada, os riscos, se existirem, e as consequências, se o paciente não for tratado ou as estratégias necessárias não forem utilizadas., 13

Por outro lado, o clínico é confrontado com a decisão de permitir que os pais estejam presentes ou não durante a consulta, com exceção de crianças muito pequenas ou com necessidades especais. Embora não haja acordo geral entre os odontopediatras, estabelecendo se um representante deve ou não ser aceito durante o tratamento odontológico,existeumatendênciaatualque mostra um aumento no envolvimento dos pais na tomada de decisão, consentimento e fornecimento de tratamento. Ter pais no escritório pode ser uma vantagem, aproveita-se a oportunidade para interagir com eles, e eles também avaliam e desenvolvem uma opinião sobre o trabalho e o tratamento afetivo. No entanto, quando os pais não podem fornecer apoio eficaz, é recomendável que permaneçam na sala de espera. Durante a fase de confinamento, a real contribuição da presença do pai deve ser levada em consideração para tornar o tratamento mais eficaz. ${ }^{7,15}$ No caso de 
o representante entrar no consultório, ele deve permanecer com a máscara de proteção.

O objetivo é sempre dar as boas-vindas ao paciente e seus pais, em um ambiente adequado para crianças, reduzindo a ansiedade e facilitando a relação DentistaPaciente-Pais, mesmo nas diferentes situações derivadas da pandemia do COVID-19.

\section{Características das roupas do dentista} ajustadas aos padrões de biossegurança durante a pandemia de COVID-19:

A roupa de atendimento do dentista mudou. Os profissionais de saúde vestem uniformes de várias cores, desenhos e estilos; diferentemente dos uniformes tradicionais (roupas brancas ou de uma única cor). Estes uniformes mais coloridos mostraram-se confortáveis e permitem uma maior amplitude de movimento. No entanto, muitos profissionais continuam preferindo $\mathrm{o}$ jaleco branco, pelo conteúdo simbólico que confere respeito e seriedade. ${ }^{7,16}$

As roupas do dentista na pandemia de COVID-19 cobrem mais o corpo e podem incluir roupas bem fechadas (macacão, "roupa de coelho") e aventais longos., 17

Deve-se utilizar respirador N95 ou a máscara cirúrgica, óculos de proteção e escudo ou proteção facial para proteger a mucosa, as membranas dos olhos, nariz e boca durante procedimentos que podem gerar respingos ou gotículas de saliva, sangue ou outros fluidos corporais. ${ }^{9}$

Durante os procedimentos que geram aerossóis, é importante a utilização do respirador N95 ou outro que ofereça um nível mais alto de proteção, como outros respiradores descartáveis com uma máscara de filtro. Se um respirador não estiver disponível para um procedimento de aerossolização, uma máscara cirúrgica e uma máscara facial devem ser usadas. ${ }^{18,19}$

As roupas do dentista para atendimento odontológico durante a pandemia de COVID-19 podem interferir na comunicação eficaz com o paciente e $\mathrm{o}$ representante; portanto, um tom de voz entusiasmado deve ser usado e a empatia deve ser aprimorada pelo olhar. A comunicação com a criança é a verdadeira chave para o bom comportamento, e o contato visual contribui para a comunicação e diminui a ansiedade. Para isso, podem ser utilizados os vídeos elaborados pela ALOP com histórias que aproximam a criança dessa nova realidade do cuidado.

\section{Características do consultorio adaptado com as novas normas de biossegurança durante a Pandemia COVID-19:}

A sala de espera desempenha um papel muito importante para a primeira impressão. Deve ser iluminada, com cores claras. Está claramente comprovado que uma clínica decorada, com pôsteres ou figuras, jogos e uma decoração simples, reduz a ansiedade à consulta. Da mesma forma, a ansiedade pré-operatória é reduzida quando as crianças participam de atividades recreativas na área de espera, ajudando a criança a relaxar, além de atuar como facilitadora da interação e comunicação entre profissionais de saúde, crianças e acompanhantes. ${ }^{7,20}$

No entanto, durante um período de pandemia, revistas, flores, brinquedos, bichos de pelúcia (brinquedos de pelúcia), livros de histórias e outros itens que possam promover a contaminação devem ser removidos do ambiente. ${ }^{21}$

Os pais devem saber disso de antemão, e 
assim podem explicar e preparar a criança, pois essas mudanças podem afetar a maneira como a criança percebe o ambiente clínico, gerando maior ansiedade. A música pode ser usada para relaxar o paciente. Por outro lado, recomenda-se levar à consulta apenas os objetos essenciais. 7, 22

O banheiro da clínica odontológica deve estar disponivel para uso, com toalhas de papel para secar as mãos e sabão antibacteriano. Este espaço deve ser desinfetado com freqüência.

O pessoal auxiliar e secretária devem ter iniciativa para lidar com situações difíceis, devem ser treinados para oferecer o material de desinfecção para usar e conhecer as indicações de cada um. ${ }^{19}$

Recomenda-se que, para a área de tratamento, luz natural, boa iluminação e ventilação adequada sejam utilizadas durante o trabalho, evite andar com frequencia em vários ambientes, use móveis e armários limpos e arrumados, com fácil acesso a todos os materiais. ${ }^{7} \mathrm{Na}$ fase crítica, tudo a ser utilizado deve ser colocado na bandeja da unidade odontológica, quando necessário, evitando o uso de recipientes e dispensadores que contribuam para a contaminação.

\section{Estrategias para alcançar a colaboração do paciente durante $o$ atendimento odontopediatrico}

O dentista deve usar todas essas estratégias eficazes para alcançar o um ambiente bom e tranquilo no atendimento odontológico. A comunicação com o paciente é a chave para o bom comportamento. ${ }^{7,23,24}$

O contato visual contribui para a comunicação e deve ser usado ainda mais nesta fase, pois a única coisa que o dentista verá são os olhos. Da mesma forma, o tom da voz é de grande importância, o que deve ser tranquilizador e entusiasmado., 25

A comunicação não verbal é amplamente aceita como mais influente que a comunicação verbal. No entanto, pacientes na odontopediatria interpretam mensagens verbais e não verbais. Essas mensagens não-verbais são enviadas através de uma variedade de comportamentos, incluindo a aparência do dentista, seu corpo, movimentos faciais e oculares. $\mathrm{O}$ rosto e os olhos são as principais fontes de informação emocional dos pacientes. ${ }^{12,16}$

O dentista deve observar e ouvir o paciente para detectar seus medos, em especial sobre o vírus, pois eles podem ter medo de contágio. Você deve ter a oportunidade de expressar seus sentimentos. Da mesma forma, tire suas dúvidas e garanta que ele e a toda equipe de trabalho estejam protegidos para evitar o contágio. $\mathrm{O}$ dentista deve sempre oferecer apoio e segurança, estar atento às expressões faciais e corporais que denotam medo: olhos fechados com força, tremores no queixo, punhos fechados, entre outros. Assim, deve promover uma comunicação eficaz com a criança. 7, 8, 26

Durante a consulta, o odontopediatra poderá usar o jogo para adaptar a criança e ajudá-la em seu processo de aprendizagem. A terapia lúdica será de grande ajuda na situação atual, pois as crianças tem uma capacidade enorme de fantasiar e podem ser introduzidas neste mundo mágico, sempre de acordo com seus interesses e idade. $^{7}$

Isso é exemplificado nas histórias propostas no anexo, para que os pacientes se acostumem a novas formas de atendimento odontológico devido ao COVID-19. (Anexos 1-6)

A criança também pode entrar e segurar 
seu brinquedo favorito desde que esteja protegido em saco plástico fácil de fechar. Através da brincadeira, a criança consegue libertar suas emoções, medo, ansiedade, raiva e até violência. A ansiedade e o medo do dentista podem influenciar o cuidado e o tratamento, tornando-se verdadeiros problemas de saúde bucal. Alguns estudos indicam que as meninas são mais ansiosas e mostram mais medo do que os meninos, mas de uma maneira menos significativa e que depende mais do que tudo da maturidade psicológica do menino. ${ }^{27}$

Estudos demonstraram que a técnica falarmostra e fazer e a distração auditiva visual (uso de vídeos) são igualmente eficazes no condicionamento de crianças antes de realizar qualquer tipo de tratamento odontológico. $^{28}$

A técnica falar-mostrar e fazer, é a técnica de dessensibilização focada de outra maneira por Addelston, é muito útil na odontologia, tanto na prevenção do desenvolvimento de medos dentários nas primeiras experiências, como na minimização da ansiedade e da má conduta associada, no paciente previamente sensibilizado. Foi amplamente aceito pelos odontopediatricos e pelos pais do paciente. O dentista pode reduzir o medo, primeiro "dizendo" à criança sobre a nova situação, o que ela sentirá e o que deve fazer; depois "mostrando a ele" o novo ambiente, elemento ou procedimentos que serão executados e, finalmente, "Fazendo" O que lhe disseram seria feito. Esse processo deve ser contínuo desde a entrada da criança no consultório médico, em todos os procedimentos envolvidos no tratamento, a fim de orientar gradualmente a criança aos estímulos que provocam ansiedade, para que ela possa lidar com a situação. As explicações dos procedimentos devem ser realizadas com linguagem apropriada de acordo com o desenvolvimento do paciente (digamos), demonstrar ao paciente com aspectos visuais, táteis, auditivos e olfativos, se necessário, o procedimento a ser executado (mostra). É importante mostrar de uma maneira não assustadora. E finalmente conclua o procedimento (faça). ${ }^{7,27,28}$

Durante a visita odontológica, tradicionalmente foi incluído um tempo para o uso da técnica falar-mostrar e fazer, mas o uso anterior de vídeos ou histórias podem ajudar a preparar o paciente para o uso de diferentes equipamentos e tratamentos. Isso pode reduzir o tempo de consulta e otimizar o desempenho do tratamento. ${ }^{22}$

Outra estratégia amplamente utilizada na odontopediatria é a modelagem ou também denominada aprendizado por imitação de mudança de comportamento, resultante da observação de outro indivíduo. A estratégia de modelagem é baseada no fato de que muitas respostas do comportamento humano são imitadas e que uma pessoa não precisa ter uma experiência para saber como agir e quais serão as conseqüências de um determinado comportamento. A observação cuidadosa pelo paciente é essencial, e essa pode ser a verdadeira situação do tratamento ou através de filmes ou vídeos. Dessa forma, quando chegar a hora de o paciente viver a experiência, ele saberá o que esperar e, assim, imitará os comportamentos que observou., 28 Entretanto, durante a pandemia do COVID-19, é uma recomendação estrita evitar a coincidência das pessoas consultório, impossibilitando a modelagem pessoalmente. Assim, o uso de vídeos ou outro material audiovisual, que também visa modelar o comportamento adequado antes, durante e após a consulta odontológica 
A técnica de modelagem usando um dos pais é valiosa. A eficácia do uso da mãe ou do pai como modelo dependerá da idade e do relacionamento com os pais. As crianças pequenas geralmente têm um vínculo mais profundo com a mãe, à medida que o vínculo com o pai evolui com a idade. $\mathrm{O}$ apoio dos pais é muito útil, especialmente em crianças pequenas, e também pode ser usado como recompensa e reforço positivo. Os pais podem nos ajudar com a estratégia de ensaio em casa. A mãe pode fingir ser a dentista e sentar a criança em uma cadeira, onde pedirá que ele abra a boca para ver os dentes, reforçando o comportamento apropriado. Os papéis podem ser revertidos, sendo a criança que substitui o dentista. ${ }^{7}$

O reforço positivo tem sido amplamente utilizado na odontopediatria. $\mathrm{O}$ uso de reforços verbais e de ação positivos durante o processo de consulta permite manter um comportamento positivo e colaborativo. ${ }^{7}$ ${ }^{24,25}$ Da mesma forma, ao final da consulta, seu bom comportamento deve sempre ser reforçado pelos esforços realizados, seja com palavras ou, se possível, objetos (que são facilmente desinfetados).

Além de obter um comportamento adequado durante a consulta, destaca-se que é necessário manter todos os hábitos que lhe permitem manter-se saudável, indicar as regras de higiene antes de se aposentar, como lavar as mãos e o rosto.

Os pais influenciam os comportamentos de saúde bucal das crianças. Sugestões aos pais, com o apoio do profissional de saúde bucal em casa, podem orientar a prevenção de cárie especialmente neste período de pandemia. ${ }^{29}$

Hábitos corretos de higiene bucal devem ser enfatizados em todos os momentos, incluindo escovação com pasta fluoretada e uso de fio dental, além de hábitos alimen- tares saudáveis, reduzindo o consumo de açúcar refinado. Durante a pandemia do COVID-19, todos os hábitos de higiene pessoal são a primeira linha de prevenção.

A ALOP elaborou um material de apoio audiovisual, com base em todas as estratégias de adaptação à consulta odontológica pediátrica e nas recomendações de biossegurança emitidas por organizações internacionais, especialmente para fornecer apoio à comunidade de famílias de pacientes latino-americanos e enfrentar de uma maneira melhor, a diferente situação gerada pela pandemia do COVID-19. Todo o material está anexado a esta publicação e é livremente acessível e utilizável. (Anexos 1-6, figuras 1-4)

\section{Autores}

Desarrollo de este artículo liderado por Alejandra Lipari Valdés (Chile), Salomon Alberto Cohen (Argentina), Rosemary Sogbe de Agell (España), Daniela Madrigal López (Costa Rica), Daniela Catalina Martínez Camus (Chile), María Gabriela Martínez Vásquez (Venezuela), Matias Rios-Erazo (Chile), como parte del Equipo Interdisciplinario COVID-19 de la Asociación Latinoamericana de Odontopediatría.

Equipo Interdisciplinario COVID-19 de la Asociación Latinoamericana de Odontopediatría:

Jenny Abanto (Brasil), Mariana Armada (Argentina), Paola Beltri (España), Marisol Carrillo Tabakman (Paraguay), Haydée Casaretto (Argentina), Jorge Luis Castillo (Perú), Mónica Gladys Cesetti (Argentina), Bertha Angélica Chávez González (Perú), Ana Claudia Rodrigues Chibinski (Brasil), Salomon Alberto Cohen (Argentina), Olga Cortés Lillo (España), Luzia Ana Da Silva de Carballo (Venezuela), Gonzalo De la Fuente Alvarez (Chile), Renée Di Nallo (Argentina), María Débora Elizabeth Dricas (Argentina), Sandra Echevarria (Brasil), Piedad Cecilia Echeverry Marin (Colombia), Laura Fedelli (Argentina), Carlos Flores-MIr (Canadá), Andrea Virgina González Carfora (Chile), Lina María Hernández Salas (Colombia), Francisco José Hernández Restrepo (Colombia), Maria Teresa Ibañez Rodriguez (Bolivia), José Carlos Pettorossi Imparato (Brasil), Alejandra Lipari Valdés (Chile), Daniela Madrigal López (Costa Rica), Daniela Catalina Martínez Camus (Chile), María Gabriela 
Martínez Vásquez (Venezuela), A. Carolina Medina Díaz (Venezuela), Kelly Maria Silva Moreira (Brasil), Elías M. Morón (Estados Unidos de América), Martha Mutis (Estados Unidos de América), Camila Palma (Perú), Gladys Mabel Peña (Argentina), Adriana Pistochini (Argentina), Paloma Planells (España), Gabriel Politano (Brasil), Matias RiosErazo (Chile), Adriana Maria Rubiano Pinzon (Colombia), Karla Mayra Rezende (Brasil), Rosa Gabriela Rondón (Venezuela), Gabriela Scagnet
(Argentina), Rosemary Sogbe de Agell (España), Marina Tavares Costa Nóbrega (Canadá), Jorgelina Valente (Argentina), Ernesto Venegas De Herrera (República Dominicana), Rosa Helena Wanderley Lacerda (Brasil), Ana Clara Zabala (Argentina), Gabriel Zambrano (Venezuela).

Información completa del Equipo Interdisciplinario COVID-19 de la Asociación Latinoamericana de Odontopediatría

\section{Referências}

1. COVID-19 Dental Services Evidence Review (CoDER) Working Group. Recommendations for the re-opening of dental services: a rapid review of international sources. Version 1.1 Actualizado 7 de mayo 2020. Disponible en: https://oralhealth.cochrane.org/sites/oralhealth.cochrane.org/files/public/ uploads/covid19_dental_reopening_rapid_review_07052020.pdf

2. Mallineni SK, Innes NP, Raggio DP, Araujo MP, Robertson MD, Jayaraman J. Coronavirus disease (COVID-19): Characteristics in children and considerations for dentists providing their care. Int J Paediatr Dent. 2020; 30: 245- 250. Disponible en: https://doi.org/10.1111/ipd.12653

3. Ruta de atención para procedimientos de Odontología Pediátrica durante la etapa de confinamiento o cuarentena de la pandemia COVID-19. Rev Odontopediatría Latinoam. 2020; 10 (2): Disponible en: https://www.revistaodontopediatria.org/ediciones/2020/2/art-1/.

4. Organización Mundial de la Salud OMS. Vías de transmisión del virus de la COVID-19: repercusiones para las recomendaciones relativas a las precauciones en materia de prevención y control de las infecciones. 29 de marzo 2020. Disponible en: https://www.who.int/es/news-room/commentaries/ detail/modes-of-transmission-of-virus-causing-covid-19-implications-for-ipc-precaution-recommendations.

5. American Academy of Pediatric Dentistry AAPD. Re-emergence pediatric dentistry. Practice checklist. Disponible en: https://www.aapd.org/about/about-aapd/news-room/checklist/

6. Klatchoian DA, Noronha JC, de Toledo OA. Adaptación del comportamiento del paciente odontopediátrico. Manual de Referencia para Procedimientos en Odontopediatría. Asociación Latinoamericana de Odontopediatría.[Internet]Segunda Edición (5) 25-36 Disponible en https://www.revistaodontopediatria.org/publicaciones/manuales/referencia-para-procedimientos-en-odontopediatria-2da-edicion/Manual-de-Referencia-para-Procedimientos-en-Odontopediatria-2da-edicion-Capitulo-5.pdf

7. Asociación Latinoamericana de Odontopediatría, Aime de Bilbao A, Figueroa de Garzón M, Sogbe de Agell R. Estrategias Psicoconductuales en la atención odontopediátrica. 2020 . En publicación.

8. Fodor A, De la Parra G. La relación paciente/Odontólogo: Algunas Consideraciones. Revist Dent de Chile. 2007; 99 (3) 21-26. Disponible en: https://anaservellonsemiologia.files.wordpress.com/2013/08/ la-relacion-odontologo-paciente.pdf

9. American Dental Association ADA. Interim Guidance for Minimizing Risk of COVID-19 Transmission. 2020. Disponible en: https://www.ada.org/ /media/CPS/Files/COVID/ADA_COVID_Int_Guidance_Treat_Pts.pdf

10. Mallineni SK, Innes NP, Raggio DP, Araujo MP, Robertson MD, Jayaraman J. Coronavirus Disease (COVID-19): Characteristics in children and considerations for dentists providing their care. Int J Paed Dent. [Internet] abril 2020: Disponible en: https://doi.org/10.1111/ipd.12653

11. Gedam K, Katre A. Scenario-Based Assessment of Children and Parents Preferences towards a Paediatric Dental Setup - An Observational Study. J Dent Med Sci. 2018; 17 (2): 32-42. Disponible en: https://www.iosrjournals.org/iosr-jdms/papers/Vol17-issue2/Version-1/I1702013242.pdf

12. Freeman R. A psychodynamic understanding of the dentist-patient interaction. Brit Dent J. 1999; 186 (10): 503-506. Disponible en: https://pubmed.ncbi.nlm.nih.gov/10379083/ 
13. Asociación Latinoamericana de Odontopediatría ALOP. Modelos de Consentimiento Informado para la Atención de Urgencias en tiempos de COVID-19. [Internet]abril 4, 2020. Disponible en: https:// www.alopodontopediatria.org/noticias/consentimiento-informado-indicados-especialmente-atenci\%C3\%B3n-emergencias-odontologicas/.

14. McHayleh N, Harfouche A, Souaid P. Techniques for managing behavior in pediatric dentistry: Comparative study of live modelling and Tell-Show-Do Based on Children's Heart Rates During Treatment. J Can Dent Assoc. 2009; 75(4): 283. Disponible en: http://www.cda-adc.ca/jcda/vol-75/ issue-4/283.html

15. Nathan JE. Eliminating pediatric behavior management problems at the outset: inviting parents into the dental operatory. J Clin Dentistry Oral Health. 2017;1(1):3-5. doi: 10.35841/oral-health.1.1.1-5

16. Alsarheed M. Children's Perception of Their Dentists. Eur J Dent. 2011; 5(2): 186-190.

17. Verbeek J, Rajamaki B, Ijaz S, Sauni R, Toomey E, Blackwood B, Tikka C, Ruotsalainen J, KilincBalci F. Personal protective equipment for preventing highly infectious diseases due to exposure to contaminated body fluids in healthcare staff. Coch Data Syst Rev. 2020; 4: CD011621. Disponible en: https:// www.cochranelibrary.com/cdsr/doi/10.1002/14651858.CD011621.pub4/epdf/full.

18. Peng X, Xu X, Li Y, Cheng L, Zhou X, Ren B. Transmission routes of 2019-nCoV and controls in dental practice. Int J Oral Sci. 2020; 12: 9. Disponible en: https://www.nature.com/articles/s41368-020-00759.pdf

19. American Academy of Pediatric Dentistry. COVID-19 Update/Coronavirus Update. Abril 2020. Disponible en: https://www.aapd.org/about/about-aapd/news-room/covid-19/

20. Shapiro M, Melmed RN, Sgan-Cohen HD, Eli I, Parush S. Behavioural and physiological effect of dental environment sensory adaptation on children's dental anxiety. Eur J Oral Sci. 2007; 115(6): 479-483. doi:10.1111/j.1600-0722.2007.00490.x

21. American Dental Association ADA. Interim Guidance for Minimizing Risk of COVID-19 Transmission. 2020. Disponible en: https://www.ada.org/ /media/CPS/Files/COVID/ADA_COVID_Int_Guidance_Treat_Pts.pdf

22. Alarco-Cadillo L, Casas L, Reyes M, Ramírez MC. Uso de dos técnicas alternativas de manejo de conducta: musicoterapia y distracción audiovisual, en el control y manejo de ansiedad en pacientes pediátricos de 5 a 10 años. Rev Odontopediatría Latinoam. 2017; 7 (1): Disponible en: https://www. revistaodontopediatria.org/ediciones/2017/1/art-3/

23. American Academy of Pediatric Dentistry. Behavior Guidance for the Pediatric Dental Patient. The Reference Manual of Pediatric Dentistry.2019-2020: 266-279. Disponible en: https://www.aapd.org/ about/about-aapd/news-room/covid-19/.

24. Wright GZ, Starkey PE, Gardner DE. Managing children's behavior in the dental office. Toronto. Mosby Company. 1983.

25. Ripa WL, Barenie JT. Manejo de la conducta odontológica del niño. Argentina: MundiSaic y F; 1984.

26. Nash DA. Engaging children's cooperation in the dental environment through effective communication. Pediatr Dent. 2006; 28(5): 455-459.

27. Sias Salas SS, Ayala Escandón CL, Pichardo Solís VA. El dibujo como medio de evaluación del miedo/ ansiedad en niños de 5 a 8 años en atención dental. Estudio descriptivo. Rev Odontopediatría Latinoam. 2018; 8 (2): Disponible en: https://www.revistaodontopediatria.org/ediciones/2018/2/art-8/

28. Loayza S, Azanza S. Eficacia de dos técnicas de acondicionamiento para la atención odontológica de niños de 6 a 10 años de edad de una escuela pública de Quito-Ecuador. Rev Odontopediatría Latinoam. 2017; 7 (2) Disponible en: https://www.revistaodontopediatria.org/ediciones/2017/2/art-4/

29. Duijster D, De Jong-Lenters M, Verrips E, van Loveren C. Establishing oral health promoting behaviours in children - parents' views on barriers, facilitators and professional support: a qualitative study. BMC Oral Health. 2015; 15: 157. Disponible en: https://www.ncbi.nlm.nih.gov/pmc/articles/ PMC4676163/

Recibido: $24 / 05 / 2020$

Aceptado: 07/06/2020

Correspondencia: e-mail: editor@revistaodontopediatria.org 
$\underline{\text { Anexo } 1}$

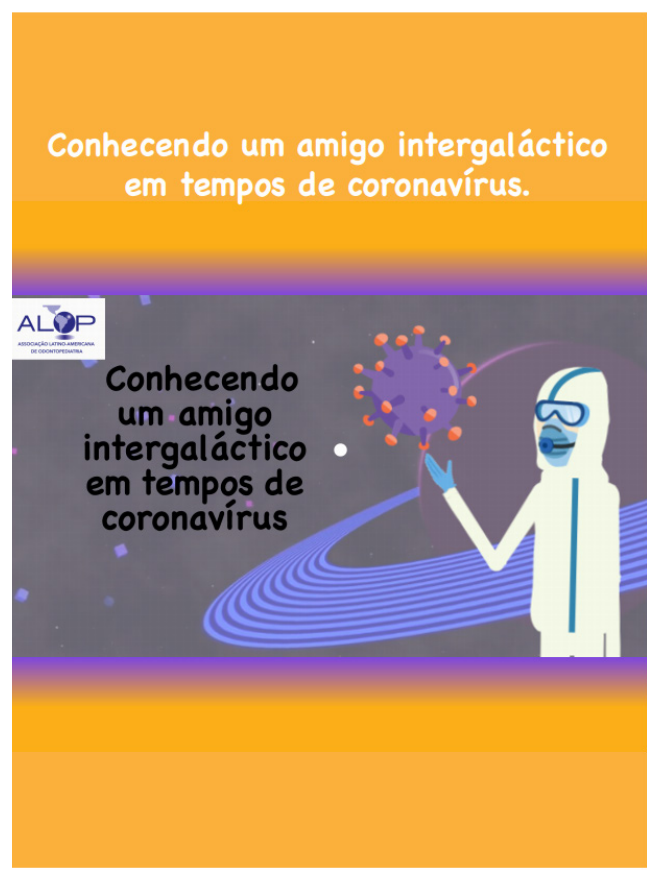

Anexo 3

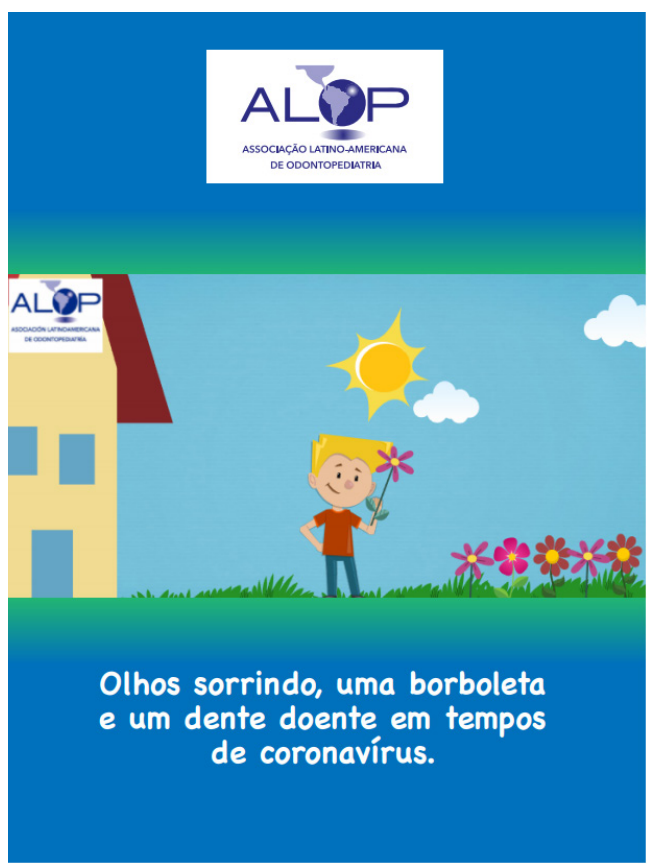

$\underline{\text { Anexo } 2}$

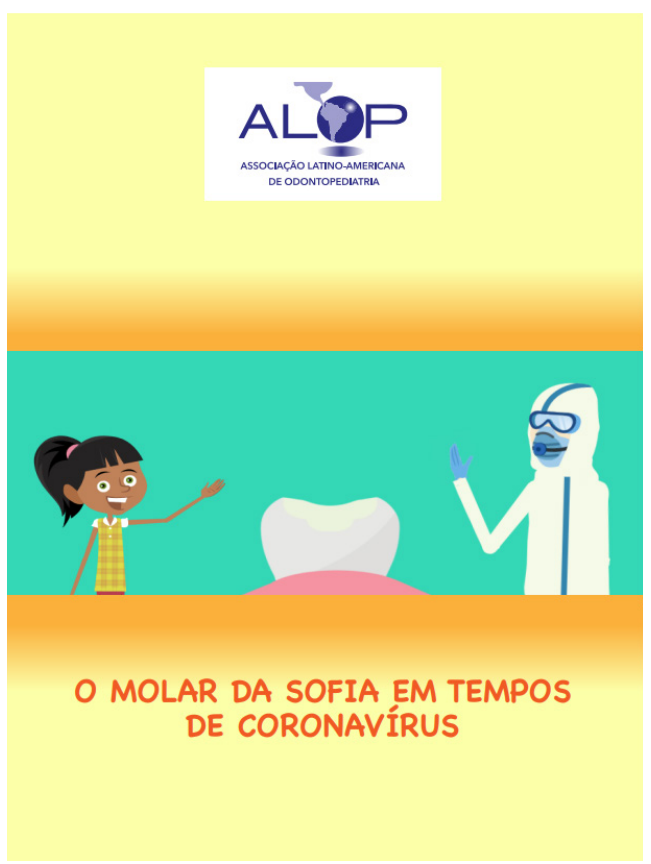

$\underline{\text { Anexo } 4}$

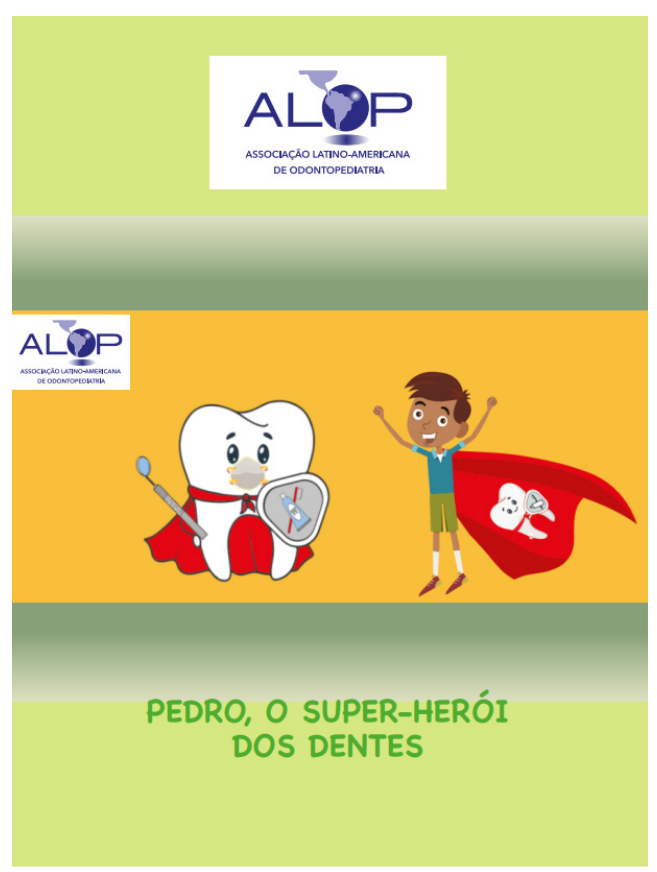


Anexo 5

\section{ALQP ASOCIACIÓN LATINOAMERICANA DE ODONTOPEDIATRÍA}

LISTA DE VERIFICAÇÃO PARA A CONSULTA

ODONTOPEDIATRICA DURANTE A PANDEMIA COVID-19

Com o objetivo de ajudar as mães, pais, responsáveis e/ou e grupo familiar de pacientes que necessitam deslocar-se para uma consulta odontológica.

Considera- se que existe diferentes etapas de isolamento social, dependendo da evolução da pandemia COVID19 em cada país. Essas medidas podem variar ao longo do tempo e e de acordo com os regulamentos e restrições locais. Orientamos consultar o seu odontopediatra para tirar qualquer dúvida.

\begin{tabular}{|c|c|c|}
\hline \multicolumn{3}{|l|}{ ANTES DE SALIR DE CASA } \\
\hline Realizar teleconsulta/ por telefone- redes sociais/ teleodontologia & $\square$ SIM & $\square \mathrm{NÃO}$ \\
\hline Envie fotos ou vídeos para o odontopediatra & $\square$ SIM & $\square \mathrm{NÃO}$ \\
\hline Prepare o paciente de maneira positiva antes da consulta (histórias, vídeos, cenário) & $\square$ SIM & $\square \mathrm{NÃO}$ \\
\hline $\begin{array}{l}\text { Medir a temperatura corporal da criança (deve ser inferior a } 37,5 \mathrm{C} \text { ) } \\
\text { Se estiver maior, suspenda a consulta e consulte o seu médico. }\end{array}$ & $\square$ SIM & $\square \mathrm{NÃO}$ \\
\hline Use roupas confortáveis & $\square$ SIM & $\square \mathrm{NÃO}$ \\
\hline $\begin{array}{l}\text { Leve apenas o essencial, incluindo uma caneta pessoal e sacolas plásticas e/ou bolsa para } \\
\text { colocar uma máscara, telefone ou outros objetos }\end{array}$ & $\square$ SIM & $\square \mathrm{NÃO}$ \\
\hline \multicolumn{3}{|l|}{$\begin{array}{l}\text { Prepare seu método de pagamento: } \\
\text { transferência }\end{array}$} \\
\hline Realize higiene bucal em seu filho & $\square$ SIM & $\square \mathrm{NÃO}$ \\
\hline $\begin{array}{l}\text { Permaneçam com máscara de proteção durante o deslocamento para o consultório } \\
\text { (paciente e acompanhante) }\end{array}$ & $\square \operatorname{siM}$ & $\square \mathrm{NÃO}$ \\
\hline $\begin{array}{l}\text { Vá diretamente à consulta, de preferência de uma maneira específica, seguindo as } \\
\text { regras de cada país. }\end{array}$ & $\square$ SIM & $\square \mathrm{NÃO}$ \\
\hline \multicolumn{3}{|l|}{ QUANDO CHEGAR AO CONSULTÓRIO } \\
\hline Mantenha sempre com máscara de proteção & $\square$ SIM & $\square \mathrm{NÃO}$ \\
\hline Realizar a limpeza dos calçados com tapetes com hipoclorito e uso de propé & $\square$ SIM & $\square \mathrm{NÃO}$ \\
\hline $\mathrm{O}$ assistente irá medir a temperatura corporal com termómetro digital $(<37,5 \mathrm{C})$ & $\square$ SIM & $\square \mathrm{NÃO}$ \\
\hline Mantenha o telefone celular higienizado & $\square$ SIM & $\square \mathrm{NÃO}$ \\
\hline Se usar luvas de proteção, estas devem ser removidas e descartadas & $\square$ SIM & $\square \mathrm{NÃO}$ \\
\hline Realizar a higiene das mãos & $\square$ SIM & $\square \mathrm{NÃO}$ \\
\hline Lavar do rosto do paciente & $\square$ SIM & $\square \mathrm{NÃO}$ \\
\hline Pode-se vestir com roupas especiais do tipo túnica, babador e gorro & $\square$ SIM & $\square \mathrm{NÃO}$ \\
\hline \multicolumn{3}{|l|}{ DURANTE A CONSULTA } \\
\hline O acompanhante deve esperar fora da sala do atendimento & $\square$ SIM & $\square \mathrm{NÃO}$ \\
\hline Acompanhante para ajudar no atendimento somente em excepcionais & $\square$ SIM & $\square \mathrm{NÃO}$ \\
\hline O paciente deve fazer bochecho antes de iniciar o tratamento & $\square$ SIM & $\square \mathrm{NÃO}$ \\
\hline O paciente deve colaborar durante o tratamento & $\square$ SIM & $\square \mathrm{NÃO}$ \\
\hline No final da consulta, realizar a higiene das mãos e do rosto do paciente & $\square$ SIM & $\square \mathrm{NÃO}$ \\
\hline Coloque a máscara no paciente e no acompanhante para sair do consultório & $\square$ SIM & $\square \mathrm{NÃO}$ \\
\hline \multicolumn{3}{|l|}{ AO CHEGAR EM CASA } \\
\hline Eles deixam sapatos na entrada da casa & $\square$ SIM & $\square \mathrm{NÃO}$ \\
\hline Remoção das máscaras & $\square$ SIM & $\square \mathrm{NÃO}$ \\
\hline Realizar a higiene das mãos e do rosto & $\square$ SIM & $\square \mathrm{NÃO}$ \\
\hline Idealmente, eles devem tomam banho com lavagem de cabelo e troca de roupa & $\square$ SIM & $\square \mathrm{NÃO}$ \\
\hline Eles devem seguir todas as orientações do dentista (recomendações e prescrições) & $\square$ SIM & $\square \mathrm{NÃO}$ \\
\hline Manter hábitos de higiene bucal adequados & $\square$ SIM & $\square \mathrm{NÃO}$ \\
\hline
\end{tabular}

TRABALHAMOS PARA FAZER AS CRIANÇAS TENHAM SORRISOS SAUdÁVEIS E FELIZES.

LEMBRE - SE DE MANTER UMA ALIMENTAÇÃO EQUILIBRADA E

FAÇA COM TODAS AS MEDIDAS DE HIGIENE ORA BUCAL APROPRIADAS.

A PREVENÇÃO É MUITO IMPORTANTE 
Anexo 6

\section{ALQP ASOCIACIÓN LATINOAMERICANA DE ODONTOPEDIATRÍA \\ Cod. $608-52$}

$\begin{aligned} & \text { INFORMAÇÃO PARA PACIENTES QUE PRECISAM DE } \\ & \text { ODONTOPEDIATICOS DURANTE A ETAPA DE PANDEMIA COVID-19 }\end{aligned}$
ASOCIACIÓN LATINOAMERICANA DE ODONTOPEDIATRÍA

Destina-se aos pais, responsáveis e ao grupo familiar de bebês, crianças, adolescentes e pacientes com deficiência, que necessitam de tratamento odontológico.

\section{INTRODUÇÃO}

Diante da situação pandêmica do COVID-19, a Associação Latinoamericana de Odontopediatria (ALOP) desenvolvemos o seguinte documento, com o objetivo de orientar os responsáveis dos pacientes no atendimento odontológico.

\section{RELAÇÃO DO COVID-19 COM O TRATAMENTO ODONTOLÓGICO}

O vírus COVID-19 é transmitido pelo contato direto com as gotas de saliva que uma pessoa infectada pode expelir quando fala, tosse ou espirra, ou também tocando em superfícies contaminadas pelo vírus. Ele pode sobreviver na superfície por várias horas, mas pode ser removido com desinfetantes comuns, como água e sabão.

É importante ter em mente que as principais medidas de prevenção do COVID-19 são as mesmas da gripe: lave as mãos com freqüência e cuide da higiene respiratória (cubra a boca ou o nariz com o cotovelo flexionado) ou com um lenço quando tossir ou espirrar e jogue esse lenço em um saco de lixo.

Atualmente, a pandemia apresenta diferentes níveis de desenvolvimento em nossos países associados da ALOP. Alguns já emergiram do total isolamento social e começaram gradualmente o atendimento odontológico, e outros ainda estão confinados em casa, de forma total ou parcial.

Assim, durante a fase de confinamento, o tratamento odontológico em pessoa só pode ser realizado em casos de emergências e urgência, para reduzir as chances de contágio e reduzir os riscos para pacientes, familiares e toda a equipe de saúde.

O odontopediatra ou o dentista responsável deve estar disponível para prestar atendimento telefônico ou em rede (telemedicina - teleodontologia), para poder dar uma assessoria e proposta de atendimento, dependendo do caso do paciente.

\section{QUAIS SÃO AS SITUAÇÕES DE URGÊNCIA ODONTOLÓGICA?}

Embora todas as condições de saúde bucal de seu filho sejam importantes, em países onde há confinamento, o atendimento odontopediátrico é direcionado exclusivamente a situações que requerem tratamento imediato para aliviar a dor, infecção, sangramento, trauma nos dentes ou na face, pacientes em tratamento ortodôntico com algum elemento solto, que corre o risco de ingerir ou aspirar ou ferir as mucosas agudas devido à incompatibilidade do aparelho ortodôntico. Nos países que já deixaram a fase crítica, o atendimento odontológico começou cuidados especiais. 


\title{
ALQP ASOCIACIÓN LATINOAMERICANA DE ODONTOPEDIATRÍA
}

Cod. $608-52$

\author{
EM CASO DE CONFINAMENTO DOMICILIAR, SE MEU FILHO APRESENTA DOR, \\ INFLAMAÇÃO, TRAUMA, O QUE EU DEVO FAZER?
}

ATENÇÃO TELEFONICA (TELEODONTOLOGIA)

1- Deve entrar em contato, por telefone ou redes sociais para o odontopediatra. su odontopediatra . Informar, de forma detalhada, específica o motivo real da consulta. Junto com o contato telefone, debe complementar as informações com fotografías ou videos que ajude o profissional a realizar o diagnóstico.

2- Atencção: O odontopediatra fará o diagnóstico de acordo com as informações fornecidas e irá orientar por telefone ou por redes, a possibilidade de tratar os sintomas, tomar medicamentos e acalmar as primeiras orientações para que se possa realizar em casa.

Você tem a responsabilidade de cumprir adequadamente todas as instruções que receber.

O gerenciamento da emergência será realizado com o objetivo de reduzir os sintomas do paciente, e o monitoramento a distância será coordenado por telemedicina, até que o confinamento seja permitido, as quarentenas terminem e outras medidas terapêticas possam ser realizadas.

3- Se o seu dentista determinar que urgente o atendimento, é essencial que você forneça ao odontopediatra as informações verdadeiras sobre a exposição ou doença do COVID-19 da criança, sua ou qualquer membro do seu grupo familiar. Isso inclui indicar se a criança, você ou um membro do seu grupo familiar teve febre ou problemas respiratórios, como perda de olfato e paladar durante os últimos 14 dias, se viajou para países em risco ou se teve ou teve contato com alguém com diagnóstico confirmado de COVID19.

Se houver suspeita de exposição, contágio ou doença ao COVID-19, você deve consultar seu médicoe seguir o protocolo COVID-19 de suas agências de saúde antes de qualquer atendimento odontológico. Somente uma vez. autorizado pelo médico, você pode receber tratamento odontológico presencial.

4- $\quad$ Se a equipe de saúde determinar que é hora de realizar atendimento odontológico de emergência, o primeiro passo é executar adequadamente, por escrito ou digital, a folha de consentimento informado que seu profissional irá enviar por telefone ou email. Esse é o primeiro passo antes do deslocamento ao dentista

CLASSIFICAÇÃO PARA TRATAMENTO DE URGÊNCIA-EMERGÊNCIA

con el tratamiento. Utilice lenguaje adecuado que permita calmarlo, darle confianza y que no le genere miedo ni ansiedad ante el tratamiento odontológico. Si la situación lo amerita muéstrele los cuentos en video para ambientarlo a la sesión odontológica.

Se seu filho precisar de cuidados que não podem adiado, todos os envolvidos devem seguir medidas que minimizem qualquer contágio. Essa é uma responsabilidade conjunta da equipe odontológica e do grupo familiar.

Tratamento. Use uma linguagem apropriada que o responsável se acalme, não crie medo ou ansiedade sobre o tratamento e fique confiante diante do tratamento. Se a situação o justificar, mostre a ele as histórias em vídeo para prepará-lo para a sessão odontológica.

Faça a mediação de temperatura comporal antes de sair de casa. Deve estar baixo de $37.5 \mathrm{C}$, caso esteja com temperatura maior, consulte primeiro o médico. 


\section{ALQP ASOCIACIÓN LATINOAMERICANA DE ODONTOPEDIATRÍA}

Cod. $608-52$

Use todas as medidas indicadas pelas autoridades e instituições de saúde: tanto a criança como o seu responsável devem usar uma máscara de proteção. Vá direto de sua casa para o consultório, sem parar em locais públicos. Não remova a máscara até que seja indicado. Ao removê-las, guarde-as em um saco plástico.

Para cumprir o distanciamento social, a consulta será feita em tempo marcado e, na recepção do consultório, você deve manter uma distância mínima de 2 metros com outras pessoas. O paciente deve comparecer ao máximo com um acompanhante da consulta. Além disso, se possível, é preferível apenas a criança entre no consultório odontológico. As exceções serão avaliadas em conjunto com o dentista responsável.

Ao chegar no cosnultório deverá higienizar as mãos com alcohol gel e em seguida lavar as mãos e rosto da criança com água e sabão. Preferencialmente deve calcar propé sob os calçados e utilizar gorro.

Os pertences pessoais devem ser deixados fora da sala de atendimento do consultório, de preferência você deve ir apenas com a carteira. Bolsas, mochilas, relógios, pulseiras, brincos ou qualquer coisa que não seja essencial, você deve deixá-lo em casa (jogos eletrônicos, telas, tablets). O telefone celular deve ser colocado em SILÊNCIO, deve ser limpo com álcool no momento da lavagem das mãos e armazenado, de preferência em um saco plástico de fechamento fácil.

O dentista e toda sua equipe seguem medidas rigorosas que minimizam a possibilidade de contágio, para as quais eles usarão equipamentos de proteção individual diferentes daqueles a que você está acostumado, incluindo máscaras especiais, viseiras/escudo, máscara, roupas anti-fluidas ou descartáveis de diferentes tipos. Verifique se essas diretrizes estão sendo seguidas pela equipe que cuida do seu filho.

Pode ser que o dentista o receba apenas com uma máscara como primeira abordagem para a criança e depois se vista com o restante dos elementos mencionados ou em outras ocasiões ele o receba com todos os elementos para proteger o paciente e os profissionais de saúde de qualquer contaminação. Você deve explicar à criança que seu dentista terá roupas especiais e diferentes

Antes de comenzar la atención se le indicará al niño que realice un enjuague con solución desinfectante. En caso de que su hijo no logre enjuagarse solo, se le higienizará su boca con una gasa.

Antes de iniciar o tratamento, a criança será instruída a fazer bochecho com solução desinfetante. Caso seu filho não consiga realizar, o cirurgião dentista irá limpar com uma gaze embebida na solução desinfetante.

Tratamento odontológico adequado será realizado para eliminar a dor, infecção ou sangramento, mas usando técnicas que minimizem a produção de aerossóis.

Se o acompanhante estiver na sala de espera, mantenha a calma e espere pacientemente pelo seu filho. Os cuidados dentários podem demorar mais do que o habitual, porque são tomadas medidas rigorosas para minimizar a possibilidade de contágio. Se você entrou na sala de consulta odontológica junto com a criança, siga as instruções da equipe de saúde. Mantenha sua máscara e não interfira no atendimento ao paciente, a menos que seja solicitado.

Após o tratamento, você deve lavar as suas mãos e as mãos e o rosto da criança. Então eles devem colocar suas máscaras de proteção novamente.

Para o pagamento da consulta, é preferível utilizar meios eletrônicos, evitando o uso de dinheiro. Se você carrega dinheiro, deve contá-lo e guardá-lo em um saco plástico. Traga sua caneta pessoal. 


\section{ALQP ASOCIACIÓN LATINOAMERICANA DE ODONTOPEDIATRÍA}

Cod. $608-52$

Mantenha o distanciamento social e volte para casa. Quando chegar em casa, retire e deixe seus sapatos, e da criança, na entrada de sua casa. O paciente e o acompanhante devem ir diretamente ao banheiro, remover as máscaras, lavar as mãos e o rosto. As máscaras devem ser descartadas em um recipiente fechado dentro de um saco. Se forem máscaras de tecido e reutilizadas, você deve deixá-las em um saco e depois lavá-las separadas do resto das roupas. Lembre-se de seguir as instruções do dentista sobre cuidados e medicamentos. Da mesma forma, para fazer o monitoramento conjunto.

CLASSIFICAÇÃO PARA TERMINAR TRATAMENTO OU CONTROLE, APÓS O TÉRMINO DO CONFINAMENTO SOCIAL

En algunos países se están iniciando las consultas odontológicas. En este caso debe mantener las medidas de resguardo. El consultorio dental estará preparado para recibirlo con las medidas necesarias de control de infección al igual que la vestimenta del odontopediatra y su equipo, que puede ser a través de bata larga, buzo, mascarillas especiales, pantalla facial, lentes protectores, gorro y lo que se defina en forma local como más apropiado.

Em alguns países, as consultas odontológicas estão retornando. Nesse caso, você deve continuar mantendo as medidas de proteção. O consultório odontológico estará preparado para recebê-lo com as medidas necessárias de controle de infecção, bem como as roupas e equipamentos do odontopediatra, que podem ser através de um avental longa, máscaras especiais, protetor/escudo facial, óculos de proteção, gorro e o todo EPI apropriado.

\section{OUTRAS CONSIDERAÇÕES}

É possivel que durante esse período, é fácil ficar impressionado com tudo o que você ouve sobre a doença de COVID-19. Também é compreensível que seus filhos estejam nervosos. Pode ser difícil para as crianças entenderem o que vêem na internet ou na televisão, ou o que ouvem dos outros, e podem ser especialmente vulneráveis a sentimentos de ansiedade, estresse e tristeza. No entanto, ter uma conversa aberta e honesta com seus filhos pode ajudá-los a entender e lidar com a situação e até dar uma contribuição positiva para os outros. As crianças podem responder ao estresse de várias maneiras, por exemplo, tornando-se mais dependentes, preocupadas, irritadas ou agitadas, tornando-se independentes ou molhando a cama. Seja solidário com as reações do seu filho, ouça as preocupações dele e ofereça mais amor e atenção. Quando possível, organize momentos de diversão e relaxamento com seu filho. Ensine-o a proteger a si mesmo e a seus amigos. Você pode encontrar outras medidas de suporte em diferentes mídias eletrônicas e páginas de suporte de organizações internacionais de saúde.

https:/Www.covid19parenting.com/spanish

Algumas maneiras recomendadas pela OMS para ajudar a interromper a disseminação do COVID-19:

- Siga o protocolo adequado ao espirrar e tossir: cubra a boca e o nariz com um cotovelo flexionado ou com um lenço de papel ao tossir ou espirrar, descarte o lenço ou papel imediatamente e lave as mãos.

- Evite tocar seu rosto (boca, nariz e olhos).

- Coloque em prática o distanciamento social: evite apertar as mãos, abraçar ou beijar outras pessoas, além de compartilhar alimentos, utensílios, copos e toalhas.

- Evite o contato direto com qualquer pessoa com sintomas semelhantes aos da gripe ou do resfriado.

- Procure ajuda médica o mais rápido possível se você ou seu fillho tiver febre, tosse ou dificuldades respiratórias. 


\section{ALQP ASOCIACIÓN LATINOAMERICANA DE ODONTOPEDIATRÍA}

Cod. $608-52$

\section{CONSIDERAÇÕES FINAIS}

Essas recomendações são baseadas nas maiores evidências científicas disponíveis até o momento, sendo o COVID19 uma doença emergente. As atualizações necessárias serão feitas de acordo com o estado da ciência a esse respeito.

Essas recomendações foram feitas de forma independente e voluntária por pesquisadores da Associação Latinoamericana de odontopediatria, sem nenhum conflito de interesse.

TRABALHAMOS PARA QUE AS CRIANÇAS TENHAM SORRISOS SAÚdÁVEIS E
FELIZES.
LEMBREM SE DE MANTEREM UMA ALIMENTAÇÃO BALANCEAdA E DE CUMPRIR
COM TODAS AS MEDIDAS DE HIGIENE BUCAL.
NESTE MOMENTO, A PREVENÇÃO GANHA UMA IMPORTÂNCIA MAIOR.

\section{BIBLIOGRAFÍA}

Asociación Latinoamericana de Odontopediatría, Aime de Bilbao A, Figueroa de Garzón M, Sogbe de Agell R. Estrategias Psicoconductuales en la atención odontopediátrica. 2020 . Libro en revisión por ALOP.

American Academy of pediatric dentistry. Behavior Guidance for the Pediatric Dental Patient. The Reference Manual of Pediatric Dentistry. [Internet] 2019-2020: 266-279. Disponible en: https://www.aapd.org/about/about-aapd/newsroom/covid-19/.

American Academy of Pediatric Dentistry. COVID-19 Update/Coronavirus Update. 2020 Abril. Disponible en: https://www.aapd.org/about/about-aapd/news-room/covid-19/.

American Dental Association ADA. Emergency Care. abril 2020. Disponible en: https://www.aapd.org/about/aboutaapd/news-room/emergency-care/.

American Dental Association ADA. Interim Guidance for Minimizing Risk of COVID-19 Transmission. [Internet] Chicago IL, 2020. Disponible en: https://www.ada.org/ /media/CPS/Files/COVID/ADA_COVID_Int_Guidance_Treat_Pts.pdf

American Dental Association ADA. What Constitutes a Dental Emergency?. Marzo 31, 2020. Disponible en:https://success.ada.org/ /media/CPS/Files/Open\%20Files/ADA_COVID19_Dental_Emergency_DDS.pdf?utm_sourc $\mathrm{e}=$ adaorg\&utm_medium=covid-resources-lp\&utm_content=cv-pm-emerg-def\&utm_campaign=covid$19 \& \_g a=2.2729136 .124928618 .1586021397-1939509346.1586021396$.

Asociación Latinoamericana de Odontopediatría ALOP. Modelos de Consentimiento Informado para la Atención de Urgencias en tiempos de COVID-19. [Internet] abril 4, 2020. Disponible en: https://www.alopodontopediatria.org/noticias/consentimiento-informado-indicados-especialmente-atenci\%C3\%B3nemergencias-odontologicas/.

Asociacion Latinoamericana de Odontopediatría. Ruta de atención para procedimientos de Odontología Pediátrica durante la etapa de confinamiento o cuarentena de la pandemia COVID-19. Rev Odontopediatría Latinoam. [Internet] 2020; 10 (2): Disponible en: https://www.revistaodontopediatria.org/ediciones/2020/2/art-1/.

Centers for Disease Control and Prevention CDC. Interim Infection Prevention and Control Recommendations for Patients With Suspected or Confirmed Coronavirus Disease 2019 (Covid-19) in Healthcare Settings. abril 2020. Disponible en: https://www.cdc.gov/coronavirus/2019-ncov/hcp/infection-controlrecommendations.html?CDC_AA_refVal=https $\% 3 \mathrm{~A} \% 2 \mathrm{~F} \% 2 \mathrm{Fwww} . \mathrm{cdc}$.gov $\% 2 \mathrm{Fcoronavirus} \% 2 \mathrm{~F} 2019$ ncov\%2Finfection-control\%2Fcontrol-recommendations.html .

Centers for Disease Control and Prevention CDC. Recommendation: Postpone Non-Urgent Dental Procedures, Surgeries, and Visits. Marzo 27, 2020. Disponible en: https://www.cdc.gov/oralhealth/infectioncontrol/statement-COVID.html . 


\section{ALQP ASOCIACIÓN LATINOAMERICANA DE ODONTOPEDIATRÍA}

Cod. 608-52

Cluver L, Lachman JM, Sherr L, Wessels I, Krug E, Rakotomalala S, Blight S, Hillis S, Bachman G, Green O, Butchart A, Tomlinson M, Ward CL, Doubt J, McDonald K. Parenting in a time of COVID-19. Lancet. 2020 Apr 11;395(10231): Disponible en:https:/www.ncbi.nlm.nih.gov/pmc/articles/PMC7146667/

COVID-19 Dental Services Evidence Review (CoDER) Working Group. Recommendations for the re-opening of dental services: a rapid review of international sources. [Internet] Version 1.1 updated 7th may 2020. Disponible en: https://oralhealth.cochrane.org/sites/oralhealth.cochrane.org/files/public/uploads/covid19_dental_reopening_rapid_revie w_07052020.pdf

Harrel SK, MOLINARI J. Aerosols and splatter in dentistry A brief review of the literature and infection control implications. JADA. 2004;135:429-437. Disponible en: https://pubmed.ncbi.nlm.nih.gov/15127864/

Kampf G, Todt D, Pfaender S, Steinmann E. Persistence of coronaviruses on inanimate surfaces and their inactivation with biocidal agents. J Hosp Infect. 2020:Disponible en: https:/www.journalofhospitalinfection.com/article/S01956701(20)30046-3/fulltext.

Klatchoian DA, Noronha JC, de Toledo OA. Adaptación del comportamiento del paciente odontopediátrico. Manual de Referencia para Procedimientos en Odontopediatría. Asociación Latinoamericana de Odontopediatría.[Internet] Segunda Edición (5) 25-36 Disponible en https:/www.revistaodontopediatria.org/publicaciones/manuales/referencia-paraprocedimientos-en-odontopediatria-2da-edicion/Manual-de-Referencia-para-Procedimientos-en-Odontopediatria-2daedicion-Capitulo-5.pdf

Mallineni SK, Innes NP, Raggio DP, Araujo MP, Robertson MD, Jayaraman J. Coronavirus Disease (COVID-19): Characteristics in children and considerations for dentists providing their care. Int J Paed Dent. [Internet] abril 2020: Disponible en: https://oi.org/10.1111/ipd.12653

Meyer B, Casamassimo P, William F Vann, FV. An Algorithm for Managing Emergent Dental Conditions for Children Volume 43, Number 3/2019. The Journal of Clinical Pediatric Dentistry. 2019;43(3):Disponible en: https://doi.org/10.17796/10534625-43.3.10

OMS. Comité Permanente entre Organismos sobre Salud Mental y Apoyo Psicosocial en Situaciones de Emergencia (GR IASC SMAPS). Mi héroe eres tú. Un libro para los niños y niñas de todo el mundo afectados por la pandemia de COVID-19. Disponible en: https://www.unicef.org/mexico/informes/mi-h\%C3\%A9roe-eres-t $\% \mathrm{C} 3 \% \mathrm{BA}$

Organización Mundial de la Salud OMS COVID-19: Materiales de comunicación. Disponible en: https://www.paho.org/es/covid-19-materiales-comunicacion

Organización Mundial de la Salud OMS. Vías de transmisión del virus de la COVID-19: repercusiones para las recomendaciones relativas a las precauciones en materia de prevención y control de las infecciones. marzo 29, 2020. Disponible en:https://www.who.int/es/news-room/commentaries/detail/modes-of-transmission-of-virus-causing-covid19-implications-for-ipc-precaution-recommendations .

Organización Mundial de la Salud OMS.Brote de enfermedad por coronavirus (COVID-19): Orientaciones para el público. Disponible en:https:/www.who.int/es/emergencies/diseases/novel-coronavirus-2019/advice-for-public

Peng X, Xu X, Li Y, Cheng L, Zhou X, Ren B. Transmission routes of 2019-nCoV and controls in dental practice. Int J Oral Sci [Internet] 2020; 12:9. Disponible en: https://www.nature.com/articles/s41368-020-0075- 9.pdf

Parenting for Lifelong Health. Disponible en: https://www.covid19parenting.com/spanish.

Sabino-Silva R, Gomes Jardim AC, Siqueira WL. Coronavirus COVID-19 impacts to dentistry and potential salivary diagnosis. Clin Oral Invest. 2002;24:1619-1621. Disponible en: https:/www.ncbi.nlm.nih.gov/pmc/articles/PMC7088419/

United Nations International Children'sEmergencyFund (Unicef)Cómo hablarle a tu hijo sobre la enfermedad por coronavirus 2019 Disponible en:- HYPERLINK "https://www.unicef.org/es/coronavirus/como-hablarle-a-tu-hijo-sobre-coronaviruscovid-19" https://www.unicef.org/es/coronavirus/como-hablarle-a-tu-hijo-sobre-coronavirus-covid-19

Van Doremalen N, Bushmaker T T, Morris DH DH, Holbrook, et al. Aerosol and Surface Stability of SARS-CoV-2 as Compared with SARS-CoV-1. N Engl J Med. abril 2020; Disponible em: https://www.nejm.org/doi/pdf/10.1056/NEJMc2004973?articleTools=true

Verbeek J, Rajamaki B, Ijaz S, Sauni R, Toomey E, Blackwood B, Tikka C, Ruotsalainen J, KilincBalci F. Personal protective equipment for preventing highly infectious diseases due to exposure to contaminated body fluids in healthcare staff. Coch $\begin{array}{llllll}\text { Data Syst } & \text { Rev } & \text { 2020;4:CD011621. }\end{array}$ https:/www.cochranelibrary.com/cdsr/doi/10.1002/14651858.CD011621.pub4/epdf/full.

Xu H, Zhong L, Deng J, Peng J, et al. High expression of ACE2 receptor of 2019-nCoV on the epithelial cells of oral mucosa. Intl J Oral Sci. 2020;12(8):Diponible en: https://oi.org/10.1038/s41368-020-0074-x. 
INSTRUCTIVO PARA PACIENTES

Atención odontológica durante la pandemia COVID-19

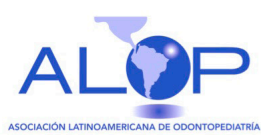

ANTES DE LA CONSULTA:

Realiza teleconsulta.
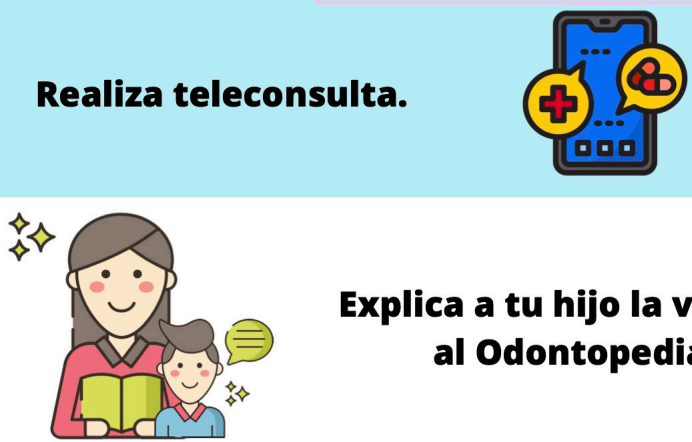

Explica a tu hijo la visita al Odontopediatra.

LLeva lo indispensable.
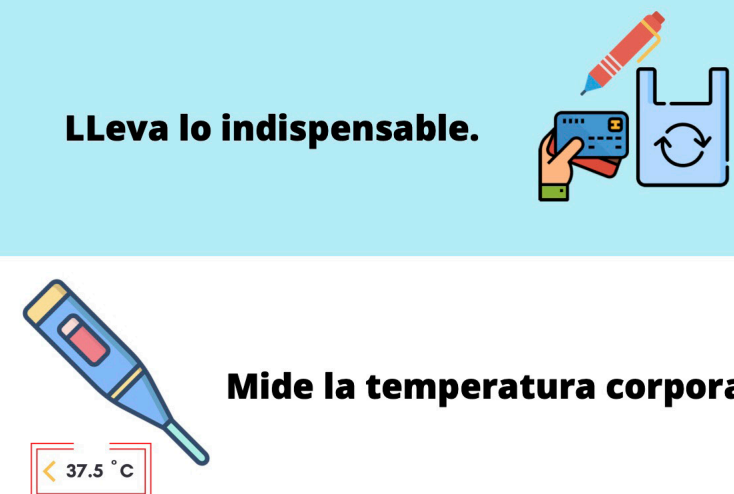

Mide la temperatura corporal.

Usa mascarilla.
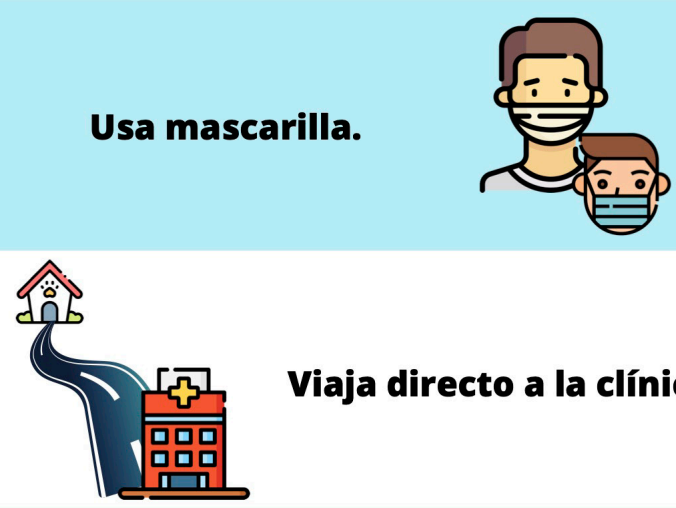

Viaja directo a la clínica.

Acude con un acompañante.

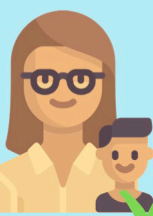

INSTRUCTIVO PARA PACIENTES

\section{Atención odontológica durante la pandemia COVID-19}

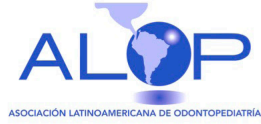

\section{AL LLEGAR A CONSULTA:}

No retires tu mascarilla.
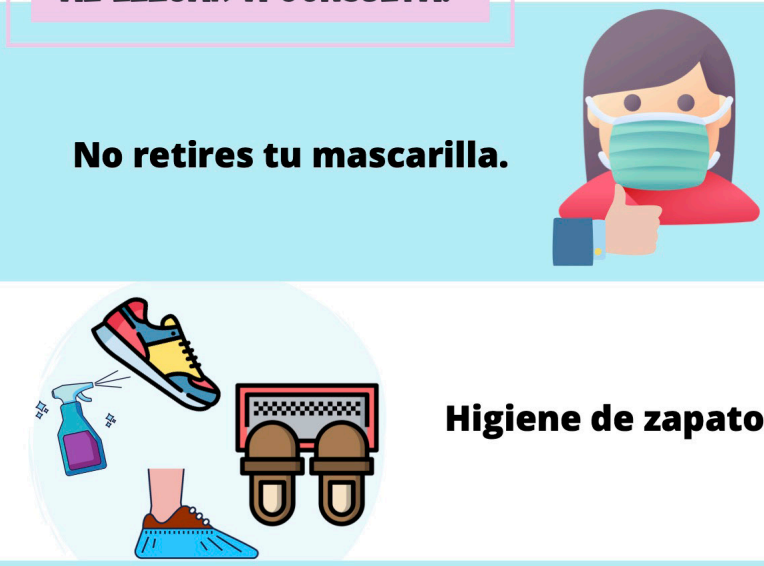

Higiene de zapatos.

Control de temperatura corporal.
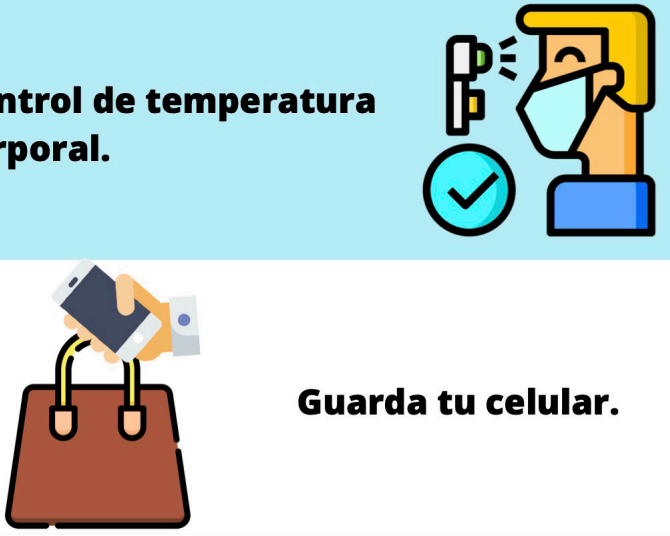

Guarda tu celular.

$$
\div-
$$

Higiene de manos y cara.
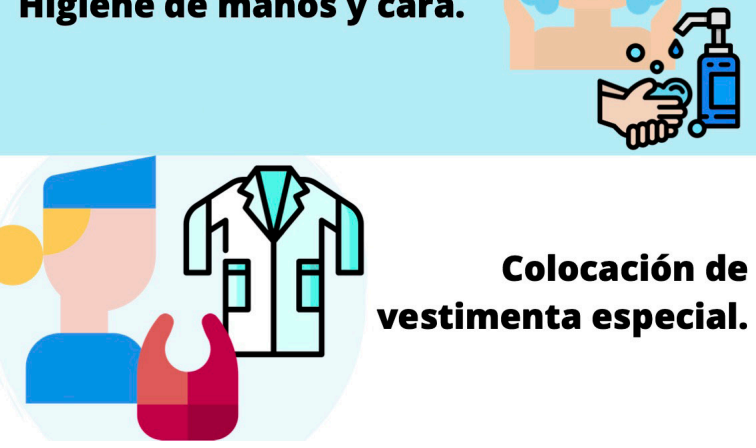

Figura 2 


\section{Atención odontológica durante la pandemia COVID-19}

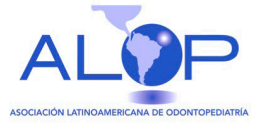

DURANTE LA ATENCIÓN:

Ingreso solo del paciente (Ideal).

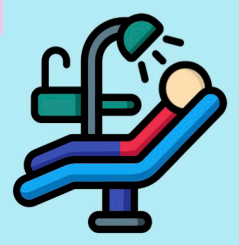

Enjuagatorio bucal.

Paciente colabora con tratamiento

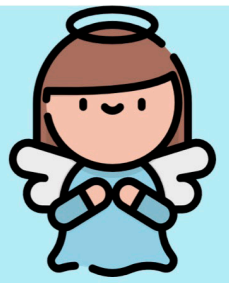

Higiene de cara.

Higiene de manos.

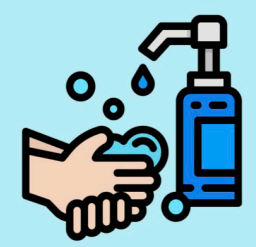

Usen mascarilla al salir.

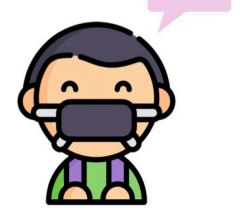

\section{Atención odontológica durante la pandemia COVID-19}

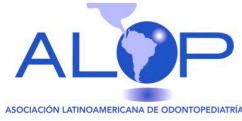

\section{AL LLEgAR A CASA:}

Zapatos en la entrada.

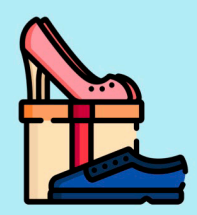

Retira la mascarilla.

\section{$\Delta$}

Lava tus manos.
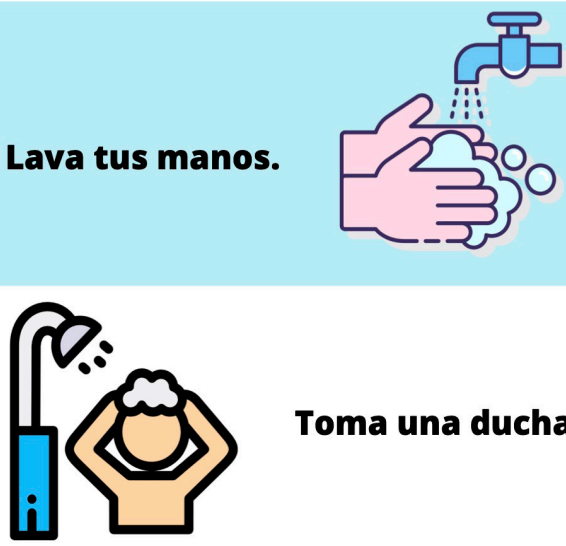

Toma una ducha.

Sigue las indicaciones del especialista.

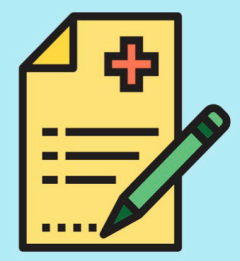

¡En estos momentos, la PREVENCIÓN es de vital importancia! 